\title{
The Melting-Pot Problem? The Persistence and Convergence of Premigration Socioeconomic Status During the Age of Mass Migration
}

\author{
by \\ Peter Catron \\ University of Washington \\ Preprint Version \\ Forthcoming in Social Forces \\ Updated 10/24/2019
}

\begin{abstract}
A long-standing debate is concerned over how long premigration socioeconomic differences persisted for immigrants and their descendants who entered at the turn-of-thetwentieth century. Some researchers argue that differences exist today, over 100 years after first arrival, while others argue that most differences disappeared after the third generation. However, none of this research has directly measured pre-migration socioeconomic status nor has it directly linked immigrants to their children. I create a new panel dataset that follows immigrants and their children from the sending country through settlement. Specifically, I link ship manifest records to census records to track how long premigration socioeconomic differences persist across generations. Passenger records provide a wealth of information of individuals including the occupation before arrival. I analyze how long premigration differences persist within and between groups. Whereas premigration socioeconomic status is associated with the first generation's economic outcomes after settlement, many of these differences disappear by the second generation. These results suggest that background is not destiny for immigrant descendants. As scholars and politicians debate about whether countries should admit primarily high-skilled or low-skilled immigrants, the results from this article tell us whether such selection policies are necessary to ensure strong migrants' performance in a period of open borders.
\end{abstract}

Acknowledgements: Dylan Connor, Leah Boustan, Zach Ward, and participants at McGill's Centre on Population Dynamics speaker series provided useful comments on this article. All mistakes are my own.

Contact Information: Email: catron@uw.edu; Mailing: Department of Sociology, University of Washington. 211 Savery Hall, Seattle, WA 98195 


\section{The Melting-Pot Problem? The Persistence and Convergence of Premigration Socioeconomic Status During the Age of Mass Migration}

From its inception to the mid-1920s, the United States had an open immigration policy with a few ethno-racial exceptions. Millions of immigrants entered the US and were subsequently absorbed into the labor market. A long-standing debate is concerned over how long initial differences in socioeconomic status persisted for these immigrant groups (Waters 1990; Waters and Lieberson 1989; Alba et al. 2001; Borjas 1994, 2001). Whereas some researchers argue that the United States is a melting-pot, quickly dissolving background differences, others argue that there was strong socioeconomic persistence for groups leading to long-term differences that lasted for over 100 years. Much of this research, however, has relied on synthetic-cohort analyses since there are few datasets that link immigrant parents to their offspring. However, with the development of panel datasets using full-count censuses and other historical sources, there has been a resurgence of research seeking to understand how long socioeconomic differences persist (Abramitzky et al. 2014; Connor 2018b; Ward 2018). This study enters this debate by investigating how long differences in premigration socioeconomic status lasted within and across immigrant groups who entered at the turn of the twentieth century. Specifically, this article develops a new dataset that tracks within-family intergenerational mobility across multiple time-points measured both in the sending country and through settlement. In addition, the data directly measure premigration socioeconomic status. Whereas prior research often measures immigrant socioeconomic status after arrival, researchers often make inferences about unmeasured socioeconomic standing before arrival (see Ferrie 1999; Connor 2018b for exceptions). Groups with higher post-migration status are shown to fare better in the labor market over time than groups with low post-migration status that is expected to persist across generations. This finding leads to calls for merit-based immigration policies that 
favor high-skilled immigrants (Borjas 1999). The results from this article help us understand whether migration restrictions or selection policies are necessary to ensure strong migrants' performance in the labor market in a period of open borders.

I focus on four major ethnic groups that came to the United States during this period that were characterized as primarily high skilled or low skilled before arrival: Italian, German, Jewish, and Russian immigrants. I build a new panel dataset of immigrant parents and their children between 1880 and 1940. I link passenger ship lists of individuals who arrived between 1880 and 1899 to their census data in 1910. Then I follow their US-born children in the 1910 census forward to their 1940 census records. Passenger records provide a wealth of information of individuals including their occupation in the sending country. First, I analyze whether premigration socioeconomic standing is predictive of first-generation outcomes and whether this varies by ethnic group. Then I analyze whether these differences persist through the second generation. Premigration differences persist through the second generation; however, these differences are severely reduced compared to the first generation and some completely disappear. In part, convergence of premigration differences occurs due to those who entered with low status being able to catch-up to those at the top of the distribution. However, the results vary based on geography, suggesting that convergence or persistence of premigration socioeconomic status is conditioned by contextual features. I conclude by discussing the features that may have allowed for convergence and persistence of background status during this era.

\section{Socioeconomic Persistence and the Melting-Pot}

Studies of intergenerational mobility are concerned with how many generations it takes to shed socioeconomic origins. The degree to which offspring reproduce their parents' social status 
points to how meritocratic societies are and indicates the fairness in systems of social stratification. Originally, researchers focused on father-son pairs to analyze social origins and destinations (e.g., Blau and Duncan 1967) that then were expanded to explore the effects across three generations (e.g., Mare 2011). Social backgrounds have lasting effects with some researchers noting that it takes up to 150 years to completely shed their origins (Mazumder 2006). This research ignores nativity, but these processes are of direct relevance to questions of immigrant assimilation and mobility. Whether immigrants are able to shed their premigration differences is central to research on international migration with some researchers arguing that premigration socioeconomic status lasts for over a century and others arguing that convergence of premigration socioeconomic status happens rather quickly.

Socioeconomic Persistence in the Age of Mass Migration

Immigrant social mobility research often points to premigration socioeconomic status as one of the most important drivers of inequality both within and between immigrant groups in the United States (Alba and Nee 2003; Portes and Rumbaut 2001). Groups with higher status backgrounds have been shown to perform better in the labor market than groups with lower status backgrounds that leads to different economic trajectories over time. These strong and persistent effects have led researchers to point out that premigration status is unlikely to disappear for immigrants and their descendants 100 to 150 years after first arrival (Borjas 1994, 1999, 2014; Ward 2019). This research suggests that premigration socioeconomic status conditions the starting points and access to mobility ladders that descendants cannot completely overcome. 
According to the above research, premigration status conditions immigrant starting points in the stratification system after arrival. Initially, immigrants often experience a socioeconomic penalty at first arrival since they are unable to transfer skills and language to obtain occupations similar to what they left (Gans 2009). However, over time, immigrants overcome these disadvantages by leveraging their human capital and ethnic and non-ethnic networks (Alba and Nee 2003). As Alba and Nee (2003) note, white-collar immigrants quickly invest in human capital and are often able to reestablish their class-based lifestyle through building their careers in the US. High-skilled immigrants move and work in places dominated by the native-born, which exposes them to individuals and families with different backgrounds. This allows highskilled immigrants to learn and adapt to native-born customs and values that are likely rewarded in the labor market. Low-skilled immigrants, on the other hand, are often reliant on their social networks to find employment in the receiving country, which increases dependence on their ethnic community. This reliance often leads to pathways of incorporation into the low-wage, low-skill part of the labor market (Alba and Nee 2003).

While premigration status influences first generation outcomes, it also has an effect on the second generation (Feliciano 2005). The starting point of mobility for immigrants and their descendants begins in their home country where the first generation develops most of their skills and are socialized into certain class positions that they later instill in their children (Feliciano and Lanuza 2017). Individuals with higher premigration status hold expectations for their children to perform well in school, which then holds a strong effect in the labor market. This process occurs at the individual-level but may also expand to the group-level since the expectations for second generation children of higher status immigrants may extend to the entire co-ethnic community (Feliciano 2006). This process suggests that groups with more positively selected individuals 
will benefit, leading highly select immigrant groups to perform well across generations while lower select immigrant groups will perform worse. Convergence of premigration status may occur within groups since lower status families may benefit from higher status families within the co-ethnic community, but between group differences remain persistent. Thus, premigration socioeconomic status has long-term consequences for the economic integration of the first generation by sorting individuals into different parts of the labor market after arrival that then influences children's trajectories.

The persistence of premigration status has been shown across empirical work suggesting that differences do not disappear for five to seven generations. In a series of influential studies, Borjas $(1994,1999,2014)$ argues that differences in human capital that immigrants bring with them endure across generations in the United States. While pointing to processes similar to the above research, Borjas argues that immigrants from different countries bring a different set of skills, which then determines the "quality" of the ethnic community and family environments after arrival. This in turn influences further human capital accumulation for the first generation that is assumed to last across multiple generations. Borjas uses a pseudo-cohort analysis to show that average group-level socioeconomic differences measured in the 1910 census persist through 1980, albeit in attenuated form, and differences are believed to persist through the fifth generation. Methodological critiques against this particular research have been widespread, however, ranging from arguments on what groups should be included (Alba, Lutz, and Vesselinov 2001; but see Borjas 2001) to the fact that Borjas includes both temporary and permanent migrants to measure socioeconomic backgrounds of groups (Ward 2018). These methodological decisions have important consequences for the results Borjas produced, but more recent research that overcomes these critiques supports the claim that socioeconomic status 
immigrants come with influences the trajectories of immigrants and their descendants for a long time.

The Melting-Pot in the Age of Mass Migration

In contrast to the above studies, many researchers note that convergence of premigration socioeconomic differences occurred for turn-of-the-twentieth century immigrants within three generations (Perlmann 1990; Waters 1990; Alba and Nee 2003; Lieberson 1980). For the most part, this research shifts focus away from human capital accumulation before arrival, while noting its significance, and points to structural features of the US economy and cultural features of immigrant groups that aided (or inhibited) social mobility. Although premigration status may be an important determinant in determining the first generation's social positions, structural features of the US push later generations into better occupational positions over time that eventually overrides the influence of the first generations' premigration status.

The dominant account for why immigrant premigration status converged quickly in the past rests on a period effect (Alba and Nee 2003; Portes and Rumbaut 2001). According to these accounts, the expansion of job ladders within manufacturing plants allowed for the upward mobility for both the first and second generation. Immigrants with backgrounds that were unfavorable to the US economy could enter the stratification system as laborers in manufacturing sectors. As immigrants gained a foothold within firms, they would then be promoted to craft and managerial positions thus allowing immigrants and their children to overcome any negative effect of their background status. Since immigrants with lower status backgrounds often entered manufacturing, the sectors would have lifted them up to positions similar to those with a higher 
status background who did not enter manufacturing sectors. Empirical work analyzing the importance of manufacturing, however, has shown that these sectors had little effect in producing mobility for both the first and second generations (Catron 2016; Waldinger 2007; Connor 2018b). Indeed, first generation immigrants who entered manufacturing firms ended their careers in positions similar to what they started - positions at the bottom (Catron 2016).

The expansion of manufacturing likely had little impact on convergence of background status for immigrant groups as organizational features of firms often prevented upward mobility for non-native-born white workers. Rather, geographic contexts likely determined economic outcomes for immigrants and their descendants since labor markets and state and local policies that target immigrants vary across regions (Sassler 2006). For instance, local and national policies began targeting the first generation's children through Americanization programs in schools. Compulsory schooling laws and their enforcement through truancy officers forced second-generation children into the classroom (Goldin and Katz 2008; Bodner 1985; Lieberson 1980). There, children learned English, about America's systems and values, and obtained USspecific human capital that they could then leverage into better occupations than what their parents worked. While family background characteristics determined entry into high school, the effects were weak suggesting that these policies began separating the second generation from their parental background status (Perlmann 1990). Indeed, the local schooling context removed the effects of premigration status, apart from children with elite backgrounds, among Irish immigrants during this period (Connor 2018b). The opportunity structure that severed the link between premigration background status and second-generation success, however, was unequal where processes unfold differently depending on the geographic context (Connor 2019b; Sassler 2006). 
Beyond the effects of local labor markets and schooling contexts, researchers have focused on how race, return migration, political categories, and cultural features of immigrant groups would have severed the link between premigration status and mobility across generations (Fox and Guglielmo 2012; Perlmann 1990; Catron 2019). Whereas these other contextual features would have an important influence on various parts of the assimilation experience, the local labor market and schooling context would have the greatest effect when determining economic integration. However, analyzing every contextual effect in both the sending and receiving society remains beyond the scope of this article. Nevertheless, contextual features would have severed the link between premigration status and later generations' success over time.

In contrast to studies that argue for strong socioeconomic persistence, other studies have found that convergence begins in the first generation that continues through the second generation. For instance, Ferrie (1999) reports that white collar workers before arrival have the greatest probability of entering white collar and skilled work soon after arrival, but the probability of becoming a white-collar worker with each additional year in the US is greatest for unskilled workers. There is catch-up within ten years of settlement between those who were in white collar and unskilled positions before arrival due to unskilled worker's ability to enter better positions over time. Although there remain significant differences, this convergence continues through the second generation. As Connor (2018b) shows, immigrants from an elite background in Ireland held a small economic advantage across generations compared to Irish immigrants with less elite backgrounds. However, all other immigrants from Ireland reported no statistically discernible difference across settlement. Rather, contextual features exerted a greater influence when determining second generation outcomes. In contrast to studies arguing for strong 
socioeconomic persistence, this research suggests that features of the United States promoted rapid economic integration that homogenized groups within a few generations.

\section{Data, Matching, and Methods}

Ship Manifest Data

To understand whether premigration socioeconomic status of immigrants is predictive of later generation's success, I use occupations from the immigrants' passenger ship manifest record available from the US National Archives and Records Administration (NARA). ${ }^{1}$ The data come from the Italians to America, Germans to America, and Russians to America files that are described in detail below. Ship manifests during this era collected a wide range of information about individuals disembarking on US soil. Beginning with the Passenger Ship Act of 1819 and later the 1855 Passenger Act, captains were required to fill out these lists or face a $\$ 50$ fine and up to six months in jail. Steamship companies were also required to pay for the individual's deportation if they were deemed ineligible for entry at arrival. The manifest data include the immigrant's name, age, sex, literacy (in some years), occupation, place of last residence, destination, country of origin, and travel compartment. In addition, the passenger lists contain information about the ship traveled on such as its name, the port of its departure, and date of arrival. This information was primarily used as a form of remote control where the information listed was used as character markers to gauge whether potential immigrants could make a living for themselves upon arrival. Filling out this information at the port of embarkation (as opposed to in the US) allowed steamship companies to prevent undesirable immigrants (those likely to come of public charge, anarchists, and polygamists) from entering the country. The manifests were

${ }^{1}$ The data includes the master files from https://aad.archives.gov/aad/index.jsp. 
also used to maintain official statistics on immigrants and to provide proof of date of entry when immigrants began the naturalization process. ${ }^{2}$ The NARA data include nearly all passengers who passed through the ports of New York, Baltimore, New Orleans, Philadelphia, and Boston from 1850 to 1899 . The representativeness of the passenger data is discussed in detail in Appendix A.

To understand socioeconomic differences of these immigrants, I code the 1,800 premigration occupations from the passenger lists using the Historical International Social Class Scheme (HISCLASS) developed by van Leeuwen and Maas (2005). I then further group these codes into five categories: white-collar, skilled blue collar, farmers, semi-skilled blue-collar, and unskilled. HISCLASS was developed to make comparisons of occupations across different periods, countries, and languages. This measure follows the International Labour Organization's 1968 International Standard Classification of Occupations (ISCO) and the 1939-1991 Dictionary of Occupational Titles (DOT). The rubric breaks occupations into several main dimensions of social class: (1) a manual-nonmanual divide, (2) skill level, (3) the degree of supervisory roles, and (4) the economic sector. Since most historical studies that use schemas based on historical intuition, HISCLASS provides more objective measures of what each occupation was (see van Leeuwen and Maas 2010 for an overview of this variable versus others). Passenger records do not identify an individual's ethnicity before 1903 . Therefore, to separate sociologically distinct groups, namely Slavic and Jewish immigrants, I use a namebased index used to characterize the probability that an individual is Jewish created by Abramitzky, Boustan, and Connor (2017). The name-based index takes individuals in the complete count censuses between 1920 and 1940 and calculates the share of individuals with a

\footnotetext{
${ }^{2}$ After the 1906 Naturalization Act, manifests were also required to include height, eye color, skin color, etc. This was to help naturalization officials confirm the identity of the immigrant when they began the naturalization process.
} 
given first or last name who spoke Yiddish or Hebrew before coming to the United States. This measure holds a value between 0 and 1 for every individual's first name and a value between 0 and 1 for every individual's last name. The first and last name index scores are added, and an individual is counted as a Jewish immigrant if the rate is at or above 1.4. The cutoff of 1.4 is used because when this index is applied to complete count censuses, the Jewish population estimates roughly match Kuznets (1975) estimates. ${ }^{3}$ Although Jewish immigrants came from both the Russian and German empires during this period, Jewish immigrants coming from Europe were ethnically very similar (Perlmann 1990). I therefore keep Jewish immigrants as one ethnicity in the analyses below. ${ }^{4}$

Table 1 presents descriptive statistics of the passenger data. For reasons discussed in the matching section below, the data are limited to men who arrived after 1880 and were between the ages of 25 and 65 in 1910. In addition, data are limited to men who arrived over the age of 15. Similarly, those who arrived as US citizens are omitted from the data. As shown, immigrant men arrived when they were relatively young on average for all groups (between 21 and 28 years) and most immigrants arrived by travelling in steerage. Germans and Russians often embarked from similar ports, while Italians left from Naples, Italy and Le Havre, France. Most immigrants disembarked at Castle Garden and Ellis Island in New York.

\footnotetext{
${ }^{3}$ Separating Jewish and non-Jewish immigrants using their name may potentially lead to misidentified individuals if Jewish immigrants had changed their name. However, name changes generally occurred after settlement (Fermaglich 2018). Since I apply the index to names before they arrive to the United States, this misidentification is likely low.

${ }^{4}$ The traditional way of identifying Jewish immigrants is to code individuals as Jewish if their mother tongue is Yiddish in the census. Many Jewish immigrants, however, did not enter the US speaking Yiddish. Robustness checks using the traditional method of identifying Jewish immigrants present similar findings as below.
} 
Despite similarities in age and mode of arrival, however, there are sharp differences in occupational background across ethnic groups. For instance, most Italians were unskilled before they arrived in the US with just 3 percent of the population being white-collar immigrants. By contrast, larger proportions of Jewish immigrants arrived with white collar and skilled backgrounds. Immigrants from the German Empire held the highest probability of being whitecollar or skilled before arrival. Whether these differences persisted after arrival, however, is the focus of the remainder of this article.

\section{[TABLE 1 HERE]}

\section{Matching and Construction of Panel Data}

To understand whether premigration skill differences persist across generations, I construct a panel dataset that links individuals across passenger records and full-count censuses. First, I take all men from the passenger records who arrived over the age of 15 between 1880 and 1899 and match them forward to their 1910 census record. ${ }^{5}$ This sample is limited to men who are between the ages of 25 and 65 in the 1910 census to ensure that they are working age. The focus on men is because women change their name at marriage and are therefore impossible to follow across time. Then I take all US-born sons between the ages of 0 and 18 of the matched first-generation immigrants and follow them forward to their 1940 census record. ${ }^{6}$ Figure 1

\footnotetext{
${ }^{5}$ Immigrants who entered under the age of 15 are usually identified as a child and do not have an occupation in the passenger lists or are assigned their father's occupation. The age of 15 and over was chosen because over $95 \%$ of those over this age had an occupation in their home country listed.

${ }^{6}$ The data only report results for children who are living with their father in the 1910 census since all background characteristics are inferred from those living in the same household. However, many teenagers would move out of the household if they lived in families with low socioeconomic status (Bodner 1985). Half of all children not living with a parent were between the ages of 16 and 18 during the time (Catron 2019). Not including children of unsuccessful parents may overestimate the level of convergence over time. As a robustness check, I also run
} 
describes the matching procedure and details what information is taken from the different datasets. Premigration variables come from the passenger record. These include HISCLASS as defined above, the year of arrival, age at arrival, and the cabin the immigrant travelled on. The 1910 census provides the occupation of the first generation and the state of settlement after 10 to 30 years in the US. The 1940 census provides the occupation of the US-born son when he is between the ages of 30 and 48 . These linked samples allow for analyses that follow occupations from the sending country through the second generation.

\section{[FIGURE 1 HERE]}

The linking procedure follows standard algorithms that match individuals using their name, age, and place of birth (Abramitzky, Boustan, and Eriksson 2014; Connor 2018a; Catron 2019). This technique links individuals from their passenger record to their 1910 census record by first standardizing first and last names by correcting for nicknames (e.g., "Pete" v. "Peter") and then uses a New York State Identification and Intelligence System (NYSIIS) phonetic coding system to account for alternate and misspelling of names. Observations from the passenger records are matched forward to the 1910 census by first looking at exact matches based on the above criteria. If there is one unique match, the procedure stops and the individual is considered matched. If there is not a match, I try matching within a 1-year age band (older and younger) and then within a 2-year age band; if there is one unique match, the individual is included in the first-generation sample. However, if there are multiple matches, or there is no match, the observation is discarded as unmatched. After the first generation is matched, I identify

all results below only including children younger than 14 . The results remain substantively unchanged. 
their US-born sons, ages 0-18, and match them forward to the 1940 census using the same matching technique. ${ }^{7}$

The first-generation link generates a final sample size of 149,683 individuals where I successfully match 12 percent of first-generation immigrants. The match rate is calculated by taking the number of successful matches and divides by the number of individuals in passenger files. The low match rate is expected due to the high return migration rates, enumeration and transcription errors across multiple sources, age heaping and a host of other issues using historical data (Abramitzky et al. 2019). However, these match rates are comparable to prior research that has linked passenger records to censuses in the US and abroad using similar matching techniques (see Alexander and Ward 2018; Spitzer and Zimran 2017; Pérez 2017). The second link generates a final sample size of 53,296 individuals where I successfully match 46 percent of second-generation sons. This higher match rate for the second generation is due to a number of reasons. First, almost all of the second generation remain in the US thus increasing their probability of being matched. Second, children are more literate and can better report their names and ages more accurately over time, younger samples tend to have lower mortality rates, and there is better transcription in the 1940 census than in earlier censuses. Third, a matched son is conditional on having a matched father, which increases the probability of a successful match

\footnotetext{
${ }^{7}$ Reasons for not matching include having a common name, return migration, and name changes. A challenge of matching passenger records to census records is that name changes could have occurred at Ellis Island. Some researchers who have matched passenger records to censuses have allowed for name Americanization to account for this issue (Spitzer and Zimran 2017; Alexander and Ward 2018). While match rates are slightly higher for these algorithms, dramatically morphing names like these methods do could lead to potential false matches. Similarly, there is little evidence that immigration agents changed names at Ellis Island as family lore often suggests, but rather name changes happened later after migration (see Cannato 2009; Fermaglich 2018). I therefore do not use these algorithms for these data.
} 
since those with a slightly higher SES are most likely to match. Appendix A provides more detail about the specific matches and the representativeness of the data to the target populations. ${ }^{8}$

Directly following immigrants and their descendants using this method overcomes many problems associated with understanding intergenerational progress. Primarily, prior research has relied on self-reported ethnicity for later generations. However, due to ethnic attrition, a highly selective portion of US-born generations stop identifying their ethnic background (Duncan et al. 2017). The linked data do not hold this problem since we know where the first generation comes from. In addition, prior work has included measures of immigrants who return to their sending country and immigrants who will permanently settle in the host country. Since return migrants are likely to be a selective population compared to those who remain in the US, estimates of convergence may be biased. By focusing on only the permanent population, we can better understand convergence by reducing selective return migration bias present in prior studies.

\section{Variables and Methods}

I begin my analyses by testing differences in outcome among first generation immigrants who arrived with different premigration statuses. I regress occupation income score in 1910 on a set of control variables including the immigrant's premigration skill and their ethnicity. The occupation income score (OCCSCORE) is calculated by IPUMS and reflects the median income of each detailed occupation observed in the 1950 census in hundreds of dollars. The score is

\footnotetext{
${ }^{8}$ A major concern with linked census data centers on whether the linking procedure generates incorrect matches or "false positives" (Bailey et al. 2017). Mismatches may attenuate results from the analyses described below that may overestimate convergence across generations. Evidence that false positives distort any conclusions is weak in research that compares different matching techniques (Abramitzky et al. 2019). As a robustness check, I also use alternative algorithms to ensure that the match does not drive the results. Results remain largely unchanged given different matching techniques.
} 
calculated by taking the median total income for each occupation published in a 1956 special report by the Census Bureau on occupational characteristics from a 3.33 percent sample of the population of both men and women. Each detailed occupation in the 1910 and 1940 census are assigned the corresponding 1950 value as a way to economically scale occupations on a continuous measure. For ease of interpretation, I convert this measure into 2010 dollars. Occupation-based earnings are the primary outcome variable used in historical census work since other information such as wages or income are not available until 1940 (Abramitzky et al. 2014; Goldstein and Stecklov 2016). This measure is often considered a proxy for "permanent" income, by which we can measure economic differences between occupations, but not within. ${ }^{9}$ By pegging occupational earnings to a single year, however, it is possible to analyze occupational movement without confounders such as changes in the income distribution.

First, I estimate outcomes of permanent immigrants to determine whether their premigration status predicts their occupational success using the first linked sample. This includes all immigrants who successfully match from the passenger record to the 1910 census and fit the data constraints defined above. Using the first linked dataset, I fit the following regression specification:

$$
\operatorname{OCCSCORE}_{i t}=\alpha+\beta_{1} \operatorname{HISCLASS}_{i}+\beta_{2} \text { ETHNICITY }_{i}+\gamma X_{i}+e
$$

\footnotetext{
${ }^{9}$ A problem with OCCSCORE is there is considerable heterogeneity in success within some occupations. In particular, the farming occupation holds considerable variability in income, which may obscure occupational differences between groups. I therefore limit my conclusions to questions of between occupational differences since it is possible that groups end up in the same occupation but have vastly different earnings.
} 
where $O C C S C O R E_{i t}$ is the occupation income score for person $i$ measured in 1910. HISCLASS is the premigration HISCLASS for the first-generation immigrant, ETHNICITY is the ethnicity of the immigrant, and $\gamma X_{i}$ is a vector of control variables that come primarily from the passenger record: age at arrival, cabin travelled on, and a year of arrival fixed effect. In addition, I add control variables from the immigrant's census record in 1910 including marital status, literacy, and a state fixed effect. Because of the year of arrival and state fixed effects in these analyses, I am implicitly comparing people who left in the same year and settled in the same place. Age in 1910 is not included since the inclusion of age at arrival and year of arrival variables make equation 1 full rank.

Equation 1 reports whether there are differences in occupational outcome given their premigration occupational status. The coefficients from the HISCLASS dummies report whether premigration status predicts occupational outcomes while the ETHNICITY variables report whether there remain differences controlling for premigration status. However, I also run an interaction between HISCLASS and ETHNICITY following the regression specification:

$$
\begin{aligned}
\text { OCCSCORE }_{i t} & =\alpha+\beta_{1} \text { HISCLASS }_{i}+\beta_{2} \text { ETHNICITY }_{i}+\beta_{3} \text { ETHNICITY }_{i} \\
& * \text { HISCLASS }_{i}+\gamma X_{i}+e
\end{aligned}
$$

This interaction model reports whether the association between occupational outcomes after settlement vary by premigration status and ethnicity. This shows whether groups with the same background variables end up in similar occupational positions and points to how long differences persist. For the first generation, the interaction model allows us to see differences between groups and whether premigration status is predictive of occupational outcomes. 
This article, however, is not only concerned about the first generation, but also whether differences persist across generations. Using the second-generation linked sample, I first use equation 1 to determine occupational outcomes in 1940. In this case, HISCLASS and ETHNICITY refer to the father's premigration status and ethnicity. The control variables include all variables used in the first-generation analysis above. In addition, I also control for the child's age in 1910 and its square. Then, I estimate the interaction model in equation 2 . Since the second-generation sample includes brothers, I cluster the standard errors at the family level. Appendix B reports how much parental occupation in 1910 influences son's occupation in 1940 by presenting intergenerational elasticities.

The control variables used in both the first- and second-generation analyses include information from both the passenger records and US censuses. From the passenger records, I include premigration occupation, the cabin the immigrant arrived on, the year of arrival, and the age of arrival. ${ }^{10}$ For the first-generation sample, I also include information about the state immigrants settled in, their marital status, and their literacy status taken from the 1910 census. For the second-generation sample, I include the variables for the first generation and also include an age control. Table 2 presents the descriptive statistics of both the first- and second-generation matched samples.

[Table 2 Here]

\section{Results}

First Generation Outcomes

\footnotetext{
${ }^{10}$ In additional analyses, I also include dummy categories for port of departure. However, there do not appear to be differences between port of departure.
} 
My analyses begin by first testing whether premigration socioeconomic status persisted after migration using the linked first-generation sample. These results qualify the link between premigration status and postmigration economic outcomes of permanent immigrants who had been in the US between 10 and 30 years. The first four models of Table 3 report differences in occupational income converted into 2010 dollars for ease of interpretation. Model 4 reports differences predicting the natural log of occupation income. I begin by first presenting unadjusted means of premigration skill and ethnicity and then add control variables from both the passenger record and 1910 census.

The unadjusted means of model 1 of Table 3 reports that all premigration occupational categories had lower occupational-based earnings after arrival than those who worked in whitecollar occupations. Farmers' low occupational earnings in this and the remaining analyses is partially driven by the propensity for farmers before migration to become a farmer after migration and the strong occupational persistence in this category thereafter. Apart from Italians who appear to have shunned farming, roughly 25 percent of individuals in the sample who were farmers before arrival became farmers after arrival. ${ }^{11}$ The occupation income score assigns all farmers in the bottom $10^{\text {th }}$ percentile of all occupations, which means that the results for any group with a high number of farmers may be artificially low. ${ }^{12}$ Nevertheless, as control variables are added, all premigration differences continue to be statistically significant. For instance, immigrants with an unskilled background are concentrated in occupations that pay roughly six

\footnotetext{
${ }^{11}$ Just 3\% of Italians who were farmers before arrival became a farmer after arrival. However, roughly $25 \%$ of Jewish and German immigrants became a farmer if their previous occupation was a farmer. Sixty-three percent of non-Jewish Russian farmers became a farmer after arrival. The next largest occupational category of post-migration occupation for farmers is a laborer. ${ }^{12}$ Alternative models omitting farmers report that premigration differences continue to be statistically significant.
} 
percent less than immigrants with a white-collar background. Similarly, immigrants with a skilled background are concentrated in occupations that pay over three percent less vis-à-vis immigrants with a white-collar background.

While premigration background is predictive of occupational success after settlement for the first generation, ethnicity also holds significant effect on socioeconomic success. Controlling for the relevant variables, Jewish, German, and Russian immigrants are concentrated in higher paying occupations than their Italian counterparts. For instance, Jewish immigrants are concentrated in occupations that pay roughly five percent more than their Italian counterparts. Thus, while socioeconomic background helps predict occupational outcomes after settlement, attachment to a particular ethnicity may help offset some of the negative impacts of socioeconomic background. Other control variables are also significant, such as the cabin the immigrant travelled on, which may capture premigration resources, and their marital and literacy status. However, consistent with previous research, premigration background has large effects on the success immigrants hold after arrival.

[Table 3 Here]

While Table 3 shows that there are differences in outcome given one's socioeconomic background, a key interest in this article is concerned with whether these skill differences persist within and between groups. Therefore, Figure 2 presents predicted occupational earnings that are derived from an interaction between ethnicity and premigration occupation controlling for the relevant variables above. The results provide the adjusted predicted occupational income for immigrants given their ethnicity and premigration background to allow for comparisons within and between groups. 
Figure 2 reports several between ethnic-group differences among first generation immigrants. For instance, immigrants who arrived with a white-collar background are expected to be concentrated in occupations that pay more than their lower status counterparts. However, white-collar Jewish immigrants are expected to have better occupational earnings than German and Italian immigrants who arrived with the same background. Italians who were in white-collar positions before arrival have the lowest predicted occupational earnings among all groups, and this trend continues throughout the remaining socioeconomic background flows. The low predicted occupational income for Italians compared to other groups may be due to a number of factors. For instance, discrimination towards Italian immigrants may have depressed occupational success, or low occupational success may be a feature of occupational concentration in construction. In addition, despite being permanent immigrants in the analysis, Italians may have been subjected to statistical discrimination by employers who believed that Italians were temporary migrants due to their high return rates and therefore did not invest in this group. Whatever the specific mechanism that led to low occupational success for Italians, there remain differences between groups with the same occupational background.

While there remain differences between groups, there are also differences within group. Having a white-collar background is associated with better predicted occupational earnings than the lower-ranked background variables. However, among the non-white-collar backgrounds, there are also important differences. Jewish and German immigrants who were skilled before arrival are expected to earn more than their semi-skilled, unskilled, and farmer counterparts. In addition, while there is no difference between semi-skilled and unskilled Jewish immigrants, semi-skilled German immigrants are concentrated in occupations that pay more than their unskilled counterparts. Italians, on the other hand, have equal occupational success given their 
socioeconomic background. Since 97 percent of all Italians entered with less than a white-collar background, there is little evidence that background status had any discernible effect on their economic trajectories, in part because other forces likely forced Italians into low-paying occupations. The next set of analyses test whether these background differences persisted through the second generation.

[Figure 2 Here]

\section{Second Generation Outcomes}

There remain differences in outcome for first generation immigrants 10 to 30 years after arrival given their premigration background. However, whether these differences persist into the second generation remains unknown. The next set of analyses use the matched 1910 to 1940 second generation sample to understand whether these premigration differences persist across generations.

Table 4 reports differences in occupational income for the second generation. Model 1 presents the unadjusted associations of parental premigration occupation on second generation occupational outcomes in 1940. As shown, there remain differences in outcome given what the first generation did prior to arrival. For instance, the second generation with fathers who were unskilled before arrival were concentrated in occupations that paid \$928 (in 2010 dollars) less than those with fathers who were in white collar positions. As control variables are added, this gap slightly shrinks, but does not disappear. Once all relevant control variables are added, children of unskilled immigrants earn $\$ 881$ less than children of white-collar immigrants. While these differences are important, the gap between premigration groups is smaller than they were for the first generation above. For instance, children of unskilled immigrants earn 3.6 percent less than children of white-collar immigrants, but this gap was six percent less in the first- 
generation analyses. Similarly, children of skilled immigrants earn roughly two percent less than children of white-collar immigrants, but this gap was over three percent in the analyses above. Thus, the results in Table 4 show that differences remain, but these differences begin to converge by the second generation.

Table 4 also reveals that differences between immigrant groups persist, controlling for premigration background. For instance, children of Jewish immigrants continue to hold an occupational advantage compared to children of Italians. That is, children of Jewish immigrants earn nearly five percent more than their Italian counterparts. This points to features of the immigrant group that creates advantages of immigrant descendants over and beyond premigration socioeconomic status. This may point to other features of the immigrant experience that creates disparities between group. However, there are no statistically discernible differences between children of Germans, Russians, and Italians. Thus, while Jewish immigrants maintain a slight advantage over the others by the second generation, this gap is also attenuated like for premigration status. Other control variables also predict occupational success for the second generation. For instance, having a parent has a large impact on second generation success. Interestingly, however, the cabin the parent travelled on, which may capture premigration resources, no longer shows any statistically discernible effect. Taken together, however, premigration differences remain in the second generation, but the effects begin to shrink for children of immigrants overall.

[Table 4 Here]

Figure 3 presents the predicted occupational income from the interaction models for both the first and second generation. The first generation adjusted predicted occupational outcomes come from Figure 2 above. The adjusted predicted occupational outcomes for the second 
generation are derived from the interaction between parental ethnicity and parental premigration occupation in Table 4 including controls. These adjusted predicted occupational incomes report whether children are concentrated in similar occupations as their parents and whether the gaps by background status persist. Since the occupational income score is pegged to a single year, 1950, as noted above, differences are not due to changes in the income distribution over time.

Figure 3 reports that all second-generation children are concentrated in occupations that pay more than the first generation. This points to the general finding of the immigrant experience that the second generation makes significant economic progress compared to their parents (Kasinitz et al. 2008). Italian second generation children have the sharpest increase in occupational income between generations leading to significant catch-up compared to the other groups. Thus, while there remains a small disadvantage given what class position their parents were in before arrival, children of Italian immigrants become concentrated in occupations that pay similar amounts to children of other ethnic backgrounds. Importantly, however, the gaps that exist in the first generation are severely attenuated in the second generation. For instance, there is a white-collar advantage for Italians in the first-generation analyses, but this advantage disappears by the second generation.

[Figure 3 Here]

To better report economic differences in the second generation, Figure 4 reports the same information as in Figure 3, but in different form. The bars in Figure 4 present the adjusted predicted occupational income for both the first and second generations that are derived from the interaction models defined above. As already noted, children of Italians are concentrated in occupations that hold similar incomes. However, they have made significant progress compared to children of other groups. By the second generation, the large occupational disadvantage for 
Italians has begun to attenuate. Whereas overall children of Italians are concentrated in occupations that pay less than many of their counterparts, these gaps are not as large as they were in the first generation. The attenuation of outcome for the Italian predicted occupational income may be due to the inclusion of various control variables included in the models. However, absent controls, children of Italians no longer have occupational disadvantage, but are instead concentrated in occupations similar to Jewish immigrants, with the exception of white-collar Jewish immigrants.

While Italians make considerable economic progress, and children of Jewish white-collar immigrants continue their elite persistence, Figure 4 also reports other processes of convergence between groups. For instance, children of white-collar German immigrants are concentrated in occupations similar to Jewish skilled, semi-skilled, and unskilled second-generation immigrants. Similarly, skilled and semi-skilled German immigrants also report being concentrated in occupations that pay similar amounts to their Jewish counterparts. Children of unskilled Italians, while holding an occupational disadvantage compared to most of the other premigration status groups, become concentrated in occupations that pay similar to unskilled German immigrants. Similarly, children of skilled Italians report being concentrated in occupations that pay similar to children of skilled German immigrants.

Within group differences also begin to disappear by the second generation. As mentioned, children of Italian immigrants are concentrated in occupations that pay similar to each other. Similarly, children of German immigrants, while showing less dramatic convergence as Italians, also report being in similar occupations. The exception being children of those with an unskilled and farming background holding lower predicted occupational income. Indeed, across the ethnic groups, children of unskilled and semi-skilled immigrants have the highest 
jump in occupational status compared to the first generation. This points to processes that make children of immigrants converge within groups as well as between.

[Figure 4 Here]

\section{Occupational Success by Geography}

The final analyses separate occupational success for first- and second-generation immigrants by geography. I run each regression as above for each region of the US separately. As mentioned, those living in the South are excluded from the sample. Due to low-cell count in some regions, I exclude non-Jewish Russians from the results, but they are available upon request. I present the predicted occupational income by geography for each ethnic group similar to Figures 2 through 4.

Figure 5 presents the adjusted predicted occupational income for first generation immigrants in 1910 given their premigration occupation. As shown, immigrants are concentrated in occupations that pay different amounts depending on their region of settlement. In all groups, those who settled in the Northeast do better in the labor market than their counterparts who settle in other parts of the country. This likely reflects the range of occupational possibilities due to the highly diversified economies of cities like New York, Philadelphia, and Boston. By contrast, Jewish and German immigrants are concentrated in occupations that pay less if they settled in the Midwest, where cities had more specialized economies. The range of opportunities within a community helps determine how well premigration socioeconomic status can be transferred to the new society. For instance, white-collar Jewish immigrants were concentrated in occupations that paid more than Jewish immigrants who arrived with lower occupational classifications 
across all regions. However, those who settled in the Midwest were concentrated in lower-paying occupations compared to immigrants who had settled in the Northeast and West. Italians who settled in the West were concentrated in occupations that paid less than Italians who settled in the other regions. Thus, occupational concentrations of first-generation immigrants are not only determined by their premigration socioeconomic status, but also the characteristics and places that receive them.

[Figure 5 Here]

Many of the geographical differences in the first-generation analyses are also present in the second-generation analyses. Figure 6 presents the adjusted predicted occupational income for the second-generation given the region they grew-up in 1910. In all cases, the second generation is concentrated in occupations that pay more than their parents similar to the above analyses. However, there remain occupational differences by region. Jewish second-generation immigrants who grew-up in the Midwest continue to hold an occupational disadvantage compared Jewish second generation immigrants who grew-up in the Northeast. Italians, on the other hand, report being concentrated in occupations that pay similar amounts regardless of parental premigration background and region. Forces that helped Italian immigrants converge into similar paying occupations should be analyzed in future studies. Nevertheless, while geographic differences persist for Jewish and German immigrants, convergence of premigration socioeconomic status within the regions is present. For instance, children of Jewish white-collar immigrants continue to hold an occupational advantage in each region, but the gap between them and other occupational backgrounds declines somewhat. Children of German immigrants are concentrated in similar paying occupations within region, with the exception of children of white-collar immigrants in the Northeast who hold an occupational advantage. The specific contextual effects 
that promote or inhibit mobility given parental premigration status should be analyzed in future research.

[Figure 6 Here]

\section{Discussion/Conclusion}

Most researchers agree that premigration status differences will have an important influence on the first generation's economic trajectories. However, considerable debate focuses on whether the effect of premigration socioeconomic status is severed across generations. Whereas some researchers argue that premigration differences last for a long time (Borjas 1994), others argue that "much is worked out by the second generation" (Perlmann 2005: 120). This article enters this debate by developing a new dataset that tracks immigrants and their children from the sending country through settlement. Premigration socioeconomic differences persist in the first generation, but they begin to disappear by the second generation with some notable exceptions. The results from this article suggest that convergence of premigration status occurred quickly for immigrant descendants at the turn of the twentieth century.

For the first generation, immigrant occupational outcomes have a strong association with their premigration status. White-collar immigrants hold higher occupational income after settlement than those who arrived with a lower background status. This suggests that immigrants' background status is important when determining first generation labor market outcomes. However, these differences begin to disappear by the second generation. The interaction models of Figures 3 and 4 suggest that most of the differences based on premigration status disappear, with some important differences. White-collar Jewish immigrants have significantly better occupational outcomes. This effect does not disappear by the second 
generation, and, likely the third. However, among the other background statuses, many of differences begin to disappear. This suggests that background is not destiny for immigrant groups who entered in the first half of the twentieth century.

This article does not directly test the conditions that allowed for shrinking occupational gaps by the second generation. However, attainment and mobility for both first- and secondgeneration immigrants vary by geography. For instance, children of unskilled Jewish immigrants fare better in the labor market if they grew up in the Northeast than children of white-collar Jewish immigrants who grew up in the Midwest. Since children do not endogenously choose their childhood locations, this points to strong contextual features that influence mobility trajectories between and within groups. The specific factors that influence mobility within regions should be analyzed in future research.

Although this article did not directly test the specific factors that influence mobility, population movement across borders yields contextual effects that can enhance or override the impact of premigration status. For instance, every immigrant enters as a foreigner and government policy sets the criteria for which citizenship can be obtained and the rights and entitlements corresponding to different formal statuses. Thus, governmental policy is likely to aid certain immigrant groups and disadvantage others leading to a system of civic stratification (Catron 2019). Similarly, immigrants enter new racial/ethnic hierarchies that may place individuals and groups in less desirable positions. The local labor market context, where immigrants transfer their premigration skills, may also reward certain positions and groups over others (Connor 2018b). At the same time, endogenous contextual influences deriving from the society of origin, such as its cultural, political, or economic conditions, influences the first generations' environment in which they grew up. Variations in culture and levels of economic 
development between home and receiving countries tend to be large and are likely to yield significant effects at the point of destination (Waldinger and Catron 2016).

While the first generation is most likely to be influenced by contextual features, their children are unlikely to be spared. Although parental influences yield strong effects on children's social destinations, children of immigrants are also confronted with a new context unlike the context that their parents grew up. During the age of mass migration, Americanization efforts targeted children forcing them to learn English and obtain US-specific human capital. These efforts also led to a rise of compulsory schooling that forced children of immigrants into the classroom likely increased both their formal skills as well as increased exposure to children of the native-born. Schooling would thus amplify referral networks that connect the second generation to employers and jobs, improve the quality and diversity of information conveyed through ethnic ties, and increase the degree of engagement and understanding of host society institutions (Lieberson 1980). Although these processes may not completely sever the link between parental premigration background and second-generation outcomes, it would severely reduce its influence as shown in this article.

The processes of mobility are also likely to differ by group. While this article focuses on the major flows of immigrants during the time, other groups such as Japanese and Chinese immigrants experienced state-level discrimination and legal barriers that may have altered their mobility trajectories. While the current methods are poorly suited to study these immigrants due to enumeration and transcription errors of these populations, future research should seek to understand non-European groups experienced mobility.

In addition to contextual features that would sever the link between premigration status and later generations' success, immigrants who arrived in the first half of the twentieth century 
were also exposed to an important period effect. Although this article does not link to the third generation since full-count censuses are not currently available past 1940 , the children of the second generation came of working age after World War II. The postwar economy was a period of tight wage compression where most individuals were paid similar amounts. The compression would likely bring the third generation from all backgrounds into similar positions. Similarly, the expanding economy and New Deal policies would have allowed almost all third-generation children to obtain middle-class lifestyles (Alba and Nee 2003). This period effect likely completely severed the link between premigration socioeconomic status and later descendants' success contrary to those who argue for long-term persistence. This trend, however, likely would have occurred absent the period effect given the amount of convergence shown in the secondgeneration analyses.

Researchers often point to the mobility trajectories of immigrants who arrived at the turnof-the-twentieth century to draw inferences about the trajectories of today's immigrants. However, much of the prior work on Europeans and their descendants has relied on pseudocohort methods, which are subject to several biases such as return migration, ethnic attrition, and the like. The development of longitudinal datasets, such as those used in this article, allow researchers to track individuals and their descendants across time. This article followed immigrants from their sending country through settlement and then tracked their children. The results suggest that convergence of premigration characteristics took less than the 100 years suggested by those arguing in favor of strong socioeconomic persistence. 


\section{Appendix A: Representativeness of Data}

I begin by presenting the representativeness of the NARA data compared to US official statistics in each year from 1880 to 1899 (or 1897 in the cases of Germany and Russia) in Figure A.1. As shown, the NARA data track the official US statistics reasonably well, with some undercounts in the later years. The undercounts in the NARA data are primarily due to a fire on Ellis Island in 1897 that destroyed some of the records (Spitzer and Zimran 2017). An undercount of individuals may bias the manifest data in that missed data may misrepresent the true distribution of occupations and places of origin among immigrants (see Erickson 1981; Ferrie 1999). However, there has been little evidence that undercounts in passenger data result in any meaningful biases when analyzing occupational outcomes over time (Ferrie 1999).

[Insert Figure A1 Here]

More important than undercounts in certain years of the passenger data is the representativeness of the matched datasets. As noted in the text, only individuals with unique names based on their age and place of birth are tracked across time. This raises the question about how representative the data are of the target population. Table A.1 presents the match rate from the passenger records to the 1910 census. The match rates calculate the share of first generation immigrants in the matched sample compared to the data universe in both the passenger records and 1910 census. The forward match rate divides the number of individuals in the matched sample by the number of immigrants in the passenger records. As shown, 11.6 percent of immigrants from the passenger records are represented in the final matched dataset. The low match rate is expected due to the high return migration rates during this period. Fiftyfive percent of all Italians, half of all Russians, and 19.6 percent of Germans returned to Europe during this era. Thus, most of the immigrants in the passenger records are not eligible to match since they would not appear in the 1910 census, especially among Italians and Russians. I also 
calculate the backward match rate that divides the matched individuals by the 1910 data universe. The match rate shows that roughly 21 percent of first generation immigrants in the 1910 census are linked to their passenger record. Both the forward and backward match rate are consistent with prior research that matches passenger records to various censuses in the US and abroad. Because premigration variables are unavailable in US censuses, the backward match rate is not shown for the passenger record variables.

\section{[Insert Table A.1 Here]}

Table A.2 presents the match rate for the second generation and presents the forward match rate since return migration is unlikely for US-born children. The data universe in Table A.2 is all sons of the matched first generation sample who were living with their father and were between the ages of 0 and 18. The matching procedure generates a final sample size of 53,296 second generation children where 43 percent of children are successfully matched from 1910 to 1940. This match rate is higher than the first generation match above since children are more literate and therefore can better report their names and ages more accurately over time, younger samples tend to have lower mortality rates, and there is better transcription in the 1940 census than in earlier censuses. Nevertheless, the probability of being matched between censuses correlates with ethnicity. Children of Italian fathers were less likely to be matched than their German and Russian counterparts.

\section{[Insert Table A.2 Here]}

Because not everyone matches, it is important to understand how representative each matched sample is to the population. Table A.3 presents the means of various variables of both the matched sample and data universe for both the first and second generation. The data universe for the first generation comes from the 1910 census from Table A.1 and the universe for the 
second generation comes from Table A.2. As shown, the first generation matched sample holds a higher occupational income, is more literate, and is younger than the target population. The second generation matched sample, on the other hand, appears to track the target population reasonably well.

[Insert Table A.3 Here] 


\section{Appendix B}

This article is concerned over whether premigration socioeconomic occupational status influences later generation's success. It does not directly analyze whether the success of the second generation depends on the success of the first generation. To analyze this issue head-on, I calculate the intergenerational elasticities (IGE) of father-son pairs in the sample. Following previous research on intergenerational persistence, I fit the specification:

$$
y_{i, g}=\alpha_{0}+\alpha_{1} y_{i, g-1}+e_{i, g}
$$

where $y_{i, g}$ is the log occupation income score for individual $i$ from generation $g$. The coefficient for $\beta_{1}$ measures the intergenerational elasticity (IGE), that measures the amount of occupational income from 1910 that a father passes to their son in 1940 . That is, $\beta_{1}$ is a persistence parameter where higher estimates mean a tighter link between father and son's occupational outcomes and therefore less mobility. I calculate the IGE of individuals and control for a quartic of son's age, a quartic of father's age, and son's age interacted with father's occupation to minimize life-cycle bias following previous research (Ward 2019). Furthermore, the second-generation sample observes son's adult outcomes when they are between 30 and 48 in the 1940 Census. This age constraint reduces any measurement error driven by life cycle bias. IGE estimates that use the 1950 OCCSCORE tend to be larger than other income/other occupational measures during this time. This is primarily because OCCSCORE overestimates the degree of persistence of farmers and sons since farmers are coded at the bottom tenth percentile of occupations (Ward 2019). I therefore also calculate the IGEs with a state fixed effect. As with the OLS regressions in the text, I cluster the standard errors at the family level. For purposes of comparison, Feigenbaum (2018) estimates 1950 occupation income elasticities for the native-born to be between roughly .22 and .44 depending on sample specification and control variables during this period. 
Table B.1 presents the IGE for various samples. The pooled sample presents the IGE for all ethnic groups included in the sample and then I calculate the IGE for each ethnic group separately. As shown, the IGE for the ethnic groups are relatively low suggesting that parental outcomes in 1910 had a low influence on second generation outcomes. However, Italians had a low IGE while Jewish immigrants had a higher IGE suggesting that Italians moved up in the occupational structure consistent with the results in the text.

[Insert Table B.1 Here] 


\section{References}

Abramitzky, Ran, Leah Boustan, and Dylan Connor. 2017. "Leaving the Enclave: Location and Economic Outcomes in the Age of Mass Migration." Working paper.

Abramitzky, Ran, Leah Boustan, and Katherine Eriksson. 2014. "A Nation of Immigrants: Assimilation and Economic Outcomes in the Age of Mass Migration." Journal of Political Economy 122(3): 467-506

Alba, Richard, Amy Lutz, and Elena Vesselinov. 2001. "How Enduring Were the Inequalities among European Immigrant Groups in the United States?” Demography 38(3): 349-356

Alba, Richard and Victor Nee. 2003. Remaking the Mainstream: Assimilation and Contemporary Immigration. Cambridge: Harvard University Press.

Alexander, Rohan and Zachary Ward. 2018. "Age at Arrival and Assimilation in the Age of Mass Migration.” The Journal of Economic History

Bailey, Martha, Connor Cole, Morgan Henderson, and Catherine Massey. 2017. "How Well Do Automated Linking Methods Perform in Historical Samples? Evidence from New Ground Truth.” Working Paper.

Blau, Peter M., and Otis Dudley Duncan. 1967. The American Occupational Structure.

Bodnar, John. 1985. The Transplanted. Bloomington: Indiana University Press.

Borjas, George. 1994. "Long-Run Convergence of Ethnic Skill Differentials: The Children and Grandchildren of the Great Migration." Industrial and Labor Relations Review 47(4): 553-573.

Borjas, George. 1999. Heaven's Door: Immigration Policy and the American Economy. Princeton: Princeton University Press. 
Borjas, George. 2001. "Long-Run Convergence of Ethnic Skill Differentials, Revisited." Demography 38(3): 357-361

Borjas, George. 2014. Immigration Economics. Cambridge: Harvard University Press.

Cannato, Vincent. 2009. American Passage: The History of Ellis Island. Harper Collins

Catron, Peter. 2016. "Made in America? Immigrant Occupational Mobility in the First Half of the Twentieth Century." American Journal of Sociology 122(2): 325-378.

Catron, Peter. 2019. "The Citizenship Advantage: Immigrant Socioeconomic Attainment across Generations in the Age of Mass Migration.” American Journal of Sociology 124(4): 9991042.

Connor, Dylan Shane. 2018a. "The Cream of the Crop? Inequality and Selectivity in Ireland during the Age of Mass Migration.” Journal of Economic History

Connor, Dylan Shane. 2018b. "Class Background, Reception Context, and Intergenerational Mobility: A Record Linkage and Surname Analysis of the Children of Irish Immigrants." International Migration Review.

Duncan, Brian, Jeffrey Grogger, Ana Sofia Leon, and Stephen Trejo. "New Evidence of Generational Progress for Mexican Americans.” NBER Working Paper 24067.

Erickson, Charlotte. 1981. "Emigration from the British Isles to the U.S.A. in 1831." Population Studies 35: 175-197.

Feigenbaum, James. 2018. "Multiple Measures of Historical Intergenerational Mobility: Iowa 1915-1940.” Economic Journal 128(612): F446-F481.

Feliciano, Cynthia. 2005. "Does Selective Migration Matter? Explaining Ethnic Disparities in Educational Attainment among Immigrants' Children." International Migration Review 39(4): 841-871. 
Feliciano, Cynthia. 2006. "Beyond the Family: The Influence of Premigration Group Status on Educational Expectations of Immigrants' Children.” Sociology of Education. 79: 281 303.

Feliciano, Cynthia and Yader Lanuza. 2017. "An Immigrant Paradox? Contextual Attainment and Intergenerational Educational Mobility.” American Sociological Review 82(1): 211241

Fermaglich, Kirsten. 2018. A Rosenberg by Any Other Name: A History of Jewish Name Changing in America. New York: New York University Press.

Ferrie, Joseph P. 1999. Yankeys Now: Immigrants in the Antebellum U.S. 1840-1860. Oxford: Oxford University Press.

Fox, Cybelle, and Thomas A. Guglielmo. 2012. "Defining America's Racial Boundaries: Blacks, Mexicans, and European Immigrants, 1890-1945.” American Journal of Sociology 118(2): 327-379.

Gans, Herbert. 2009. “First Generation Decline: Downward Mobility among Refugees and Immigrants." Ethnic and Racial Studies 32(9): 1658-1670.

Goldin, Claudia and Lawrence Katz. 2008. The Race between Education and Technology. Cambridge: Harvard University Press.

Goldstein, Joshua R. and Guy Stecklov. 2016. "From Patrick to John F. Ethnic Names and Occupational Success in the Last Era of Mass Migration." American Sociological Review Kasinitz, Philip, Mary Waters, John Mollenkopf, and Jennifer Holdaway. 2009. Inheriting the City: The Children of Immigrants Come of Age. Russell Sage Foundation

Kuznets, Stanley. 1975. "Immigration of Russian Jews to the United States: Background and Structure." Charles Warren Center for Studies in American History. 
Lieberson, Stanley. 1980. A Piece of the Pie: Blacks and White Immigrants since 1880. Berkeley: University of California Press.

Lieberson, Stanley and Mary Waters. 1990. From Many Strands: Ethnic and Racial Groups in Contemporary America. New York: Russell Sage Foundation.

Mare, Robert. 2011. “A Multigenerational View of Inequality.” Demography 48(1): 1-13

Mazumder, Bhashkar. 2006. "Fortunate Sons: New Estimates of Intergenerational Mobility in the United States Using Social Security Earnings Data.” The Review of Economics and Statistics 87(2): 235-255

Pérez, Santiago. 2018. "The (South) American Dream: Mobility and Economic Outcomes of First- and Second-Generation Immigrants in the $19^{\text {th }}$-Century Argentina." The Journal of Economic History 77(4): 971-1006

Perlmann, Joel. 1990. Ethnic Differences: Schooling and Social Structure among the Irish, Italians, Jews, and Blacks in an American City, 1880-1935. Cambridge: Cambridge University Press.

Perlmann, Joel. 2005. Italians Then, Mexicans Now: Immigrant Origins and Second Generation Progress, 1890 to 2000. New York: Russell Sage Foundation.

Portes, Alejandro and Ruben Rumbaut. 2001. Legacies: the story of the immigrant second generation. Berkeley: University of California Press.

Sharon Sassler. 2006. "School Participation of Immigrant Youths in the Early $20^{\text {th }}$ Century: Integration or Segmented Assimilation?" Sociology of Education. 79(1):1-24.

Spitzer, Yannay and Ariell Zimran. 2017. "Migrant Self-Selection: Anthropometric Evidence from the Mass Migration of Italians to the United States, 1907-1925.” Working Paper. 
van Leeuwen, Marco, and Ineke Maas. 2005. "A Short Note on HISCLASS." http://historyofwork.isg.nl/docs/hisclass-brief.doc.

van Leeuwen, Marco, and Ineke Maas. 2010. "Historical studies of social mobility and stratification." Annual Review of Sociology 36: 429-451.

Waldinger, Roger. 2007. “Did Manufacturing Matter? The Experience of Yesterday's Second Generation: A Reassessment.” International Migration Review 41(1) 3-39.

Waldinger, Roger and Peter Catron. 2016. "Modes of Incorporation: A Conceptual and Empirical Critique." Journal of Ethnic and Migration Studies 42(1): 23-53

Ward, Zachary. 2019. “The Not-So-Hot Melting Pot: The Persistence of Outcomes for Descendants of the Age of Mass Migration.” Working Paper.

Waters, Mary. 1990. Ethnic Options: Choosing Identities in America. Berkeley: University of California Press. 
Immigrant (G1)

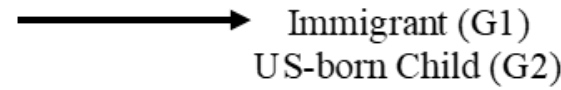

(Link 1)
US-born Child (G2)

(Link 2)

Variables

Variables Variables

Premigration Occupation (G1)

Occupation (G1)

Occupation (G2)

Year of Arrival (G1)

Age at Arrival (G1)

Marital Status (G1)

Literacy (G1)

Cabin (G1)

State (G1, G2)

Age (G1, G2)

Figure 1: Linking procedure and variables obtained from each dataset.
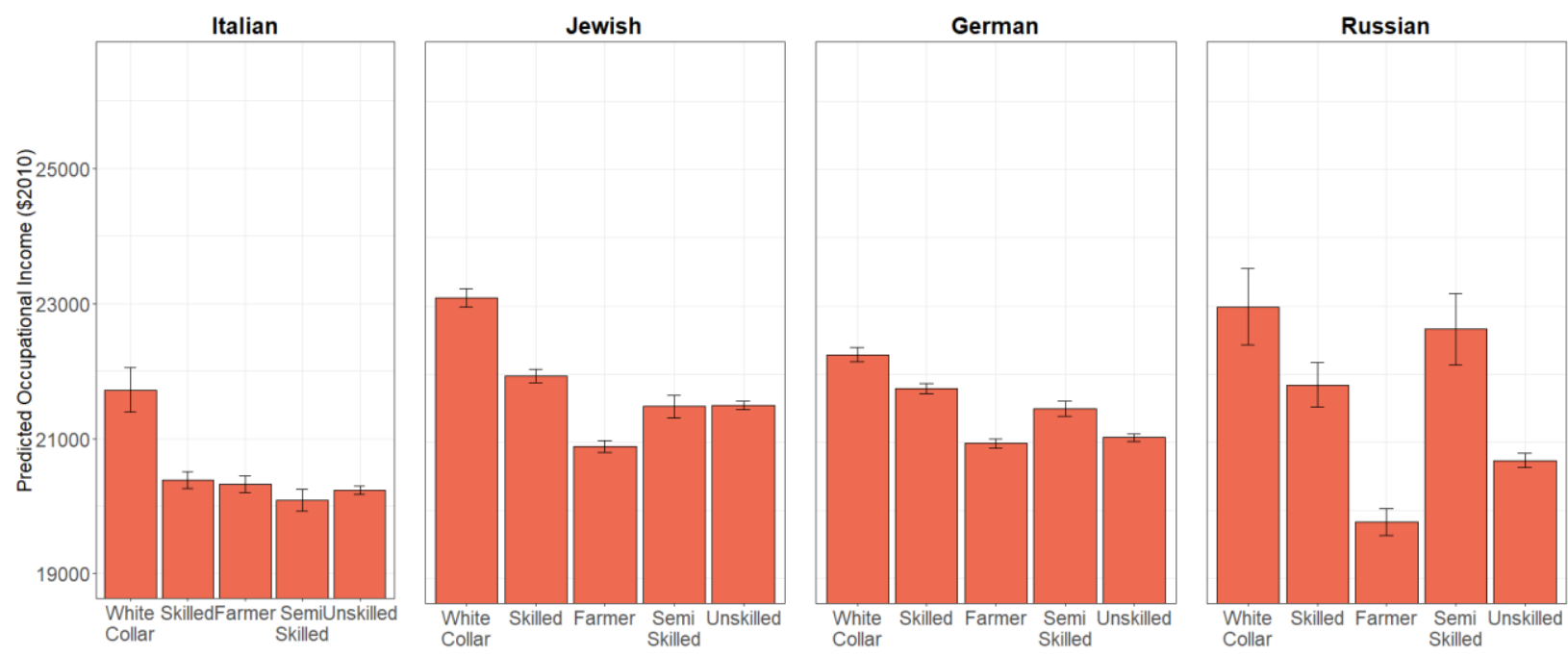

Figure 2: Adjusted Predicted Occupational Outcomes for the first generation.

Note: the adjusted predicted occupational incomes are derived from an interaction effect between ethnicity and premigration socioeconomic status. This model controls for premigration status, ethnicity, arrival age of the immigrant, the class of ship, martial status, literacy, year of arrival, and state lived in. Premigration occupations are classified by applying the HISCLASS rubric to occupations on the passenger records: HISCLASS 1-5 white collar; HISCLASS 6-7 skilled blue-collar; HISCLASS 8 farmers; HISCLASS 9 semiskilled; HISCLASS 10-12 unskilled. 

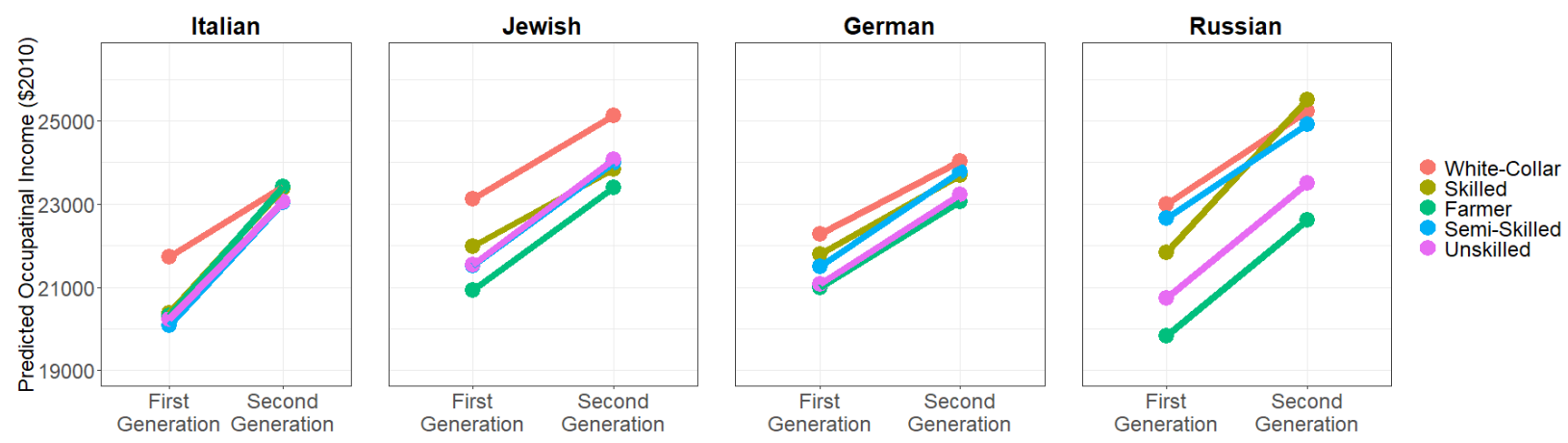

Figure 3: Adjusted predicted occupational income for first and second generation immigrants.

Note: the adjusted predicted occupational incomes are derived from an interaction effect between ethnicity and premigration socioeconomic status. The first generation models control for premigration status, ethnicity, arrival age of the immigrant, the class of ship, martial status, literacy, year of arrival, and state lived in. The second generation models control for these same parental characteristics as well as child's age. Premigration occupations are classified by applying the HISCLASS rubric to occupations on the passenger records: HISCLASS 1-5 white collar; HISCLASS 6-7 skilled blue-collar; HISCLASS 8 farmers; HISCLASS 9 semiskilled; HISCLASS 10-12 unskilled.
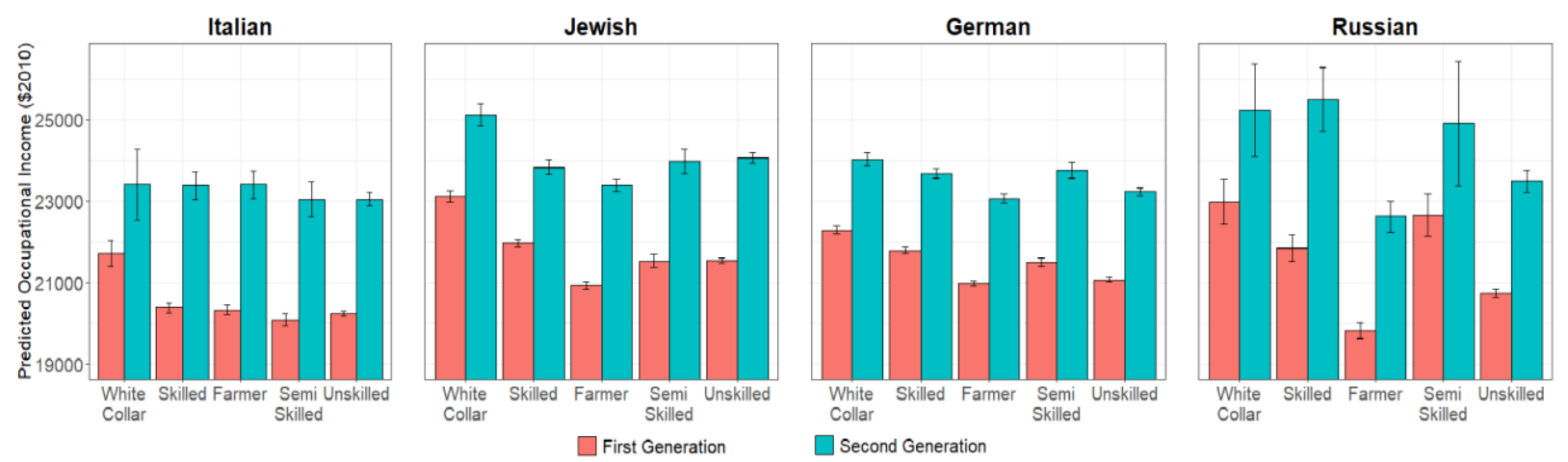

Figure 4: Adjusted predicted occupational income for first and second generation immigrants.

Note: the adjusted predicted occupational incomes are derived from an interaction effect between ethnicity and premigration socioeconomic status. The first generation models control for premigration status, ethnicity, arrival age of the immigrant, the class of ship, martial status, literacy, year of arrival, and state lived in. The second generation models control for these same parental characteristics as well as child's age. Premigration occupations are classified by applying the HISCLASS rubric to occupations on the passenger records: HISCLASS $1-5$ white collar; HISCLASS 6-7 skilled blue-collar; HISCLASS 8 farmers; HISCLASS 9 semiskilled; HISCLASS 10-12 unskilled. 


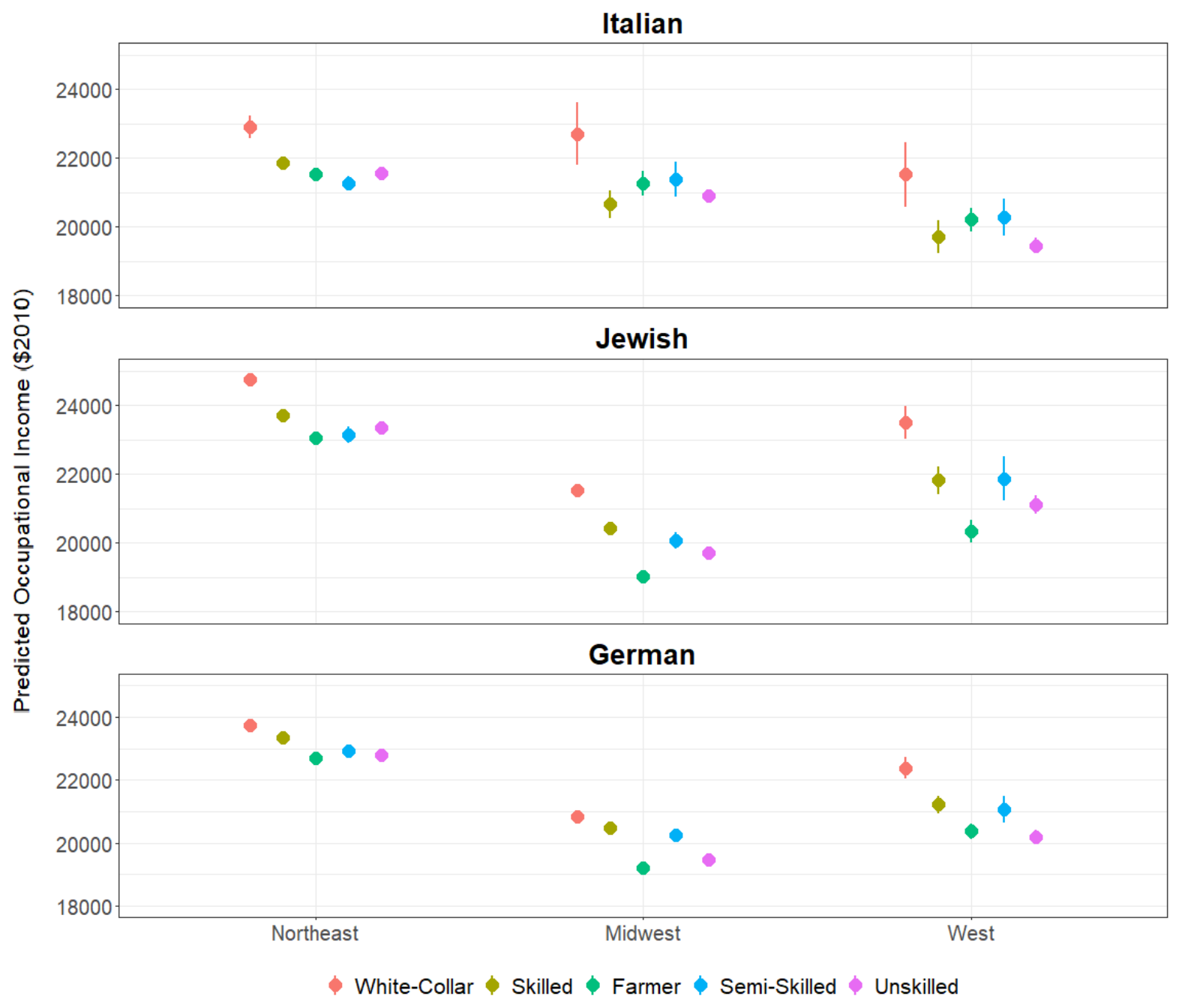

Figure 5: Adjusted predicted occupational income for first generation immigrants by geography.

Note: the adjusted predicted occupational incomes are derived from an interaction effect between ethnicity and premigration socioeconomic status within each geographic region. The models control for premigration status, ethnicity, arrival age of the immigrant, the class of ship, martial status, literacy, and year of arrival. Premigration occupations are classified by applying the HISCLASS rubric to occupations on the passenger records: HISCLASS 1-5 white collar; HISCLASS 6-7 skilled blue-collar; HISCLASS 8 farmers; HISCLASS 9 semiskilled; HISCLASS 10-12 unskilled. 


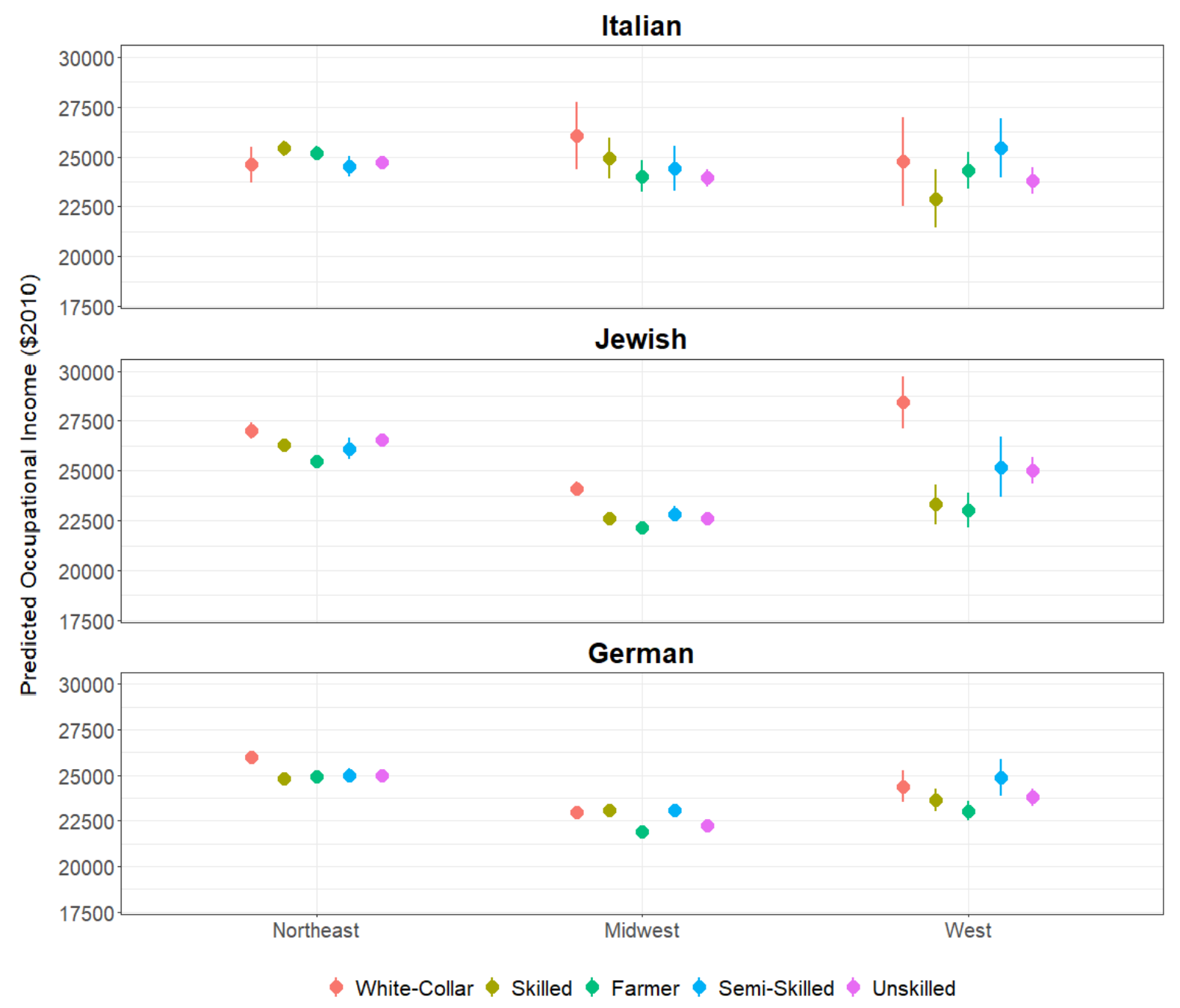

Figure 6: Adjusted predicted occupational income for second generation immigrants by geography.

Note: the adjusted predicted occupational incomes are derived from an interaction effect between ethnicity and premigration socioeconomic status. The models control for premigration status, ethnicity, arrival age of the immigrant, the class of ship, martial status, literacy, year of arrival, and child's age. Premigration occupations are classified by applying the HISCLASS rubric to occupations on the passenger records: HISCLASS 1-5 white collar; HISCLASS 6-7 skilled blue-collar; HISCLASS 8 farmers; HISCLASS 9 semiskilled; HISCLASS 10-12 unskilled. 

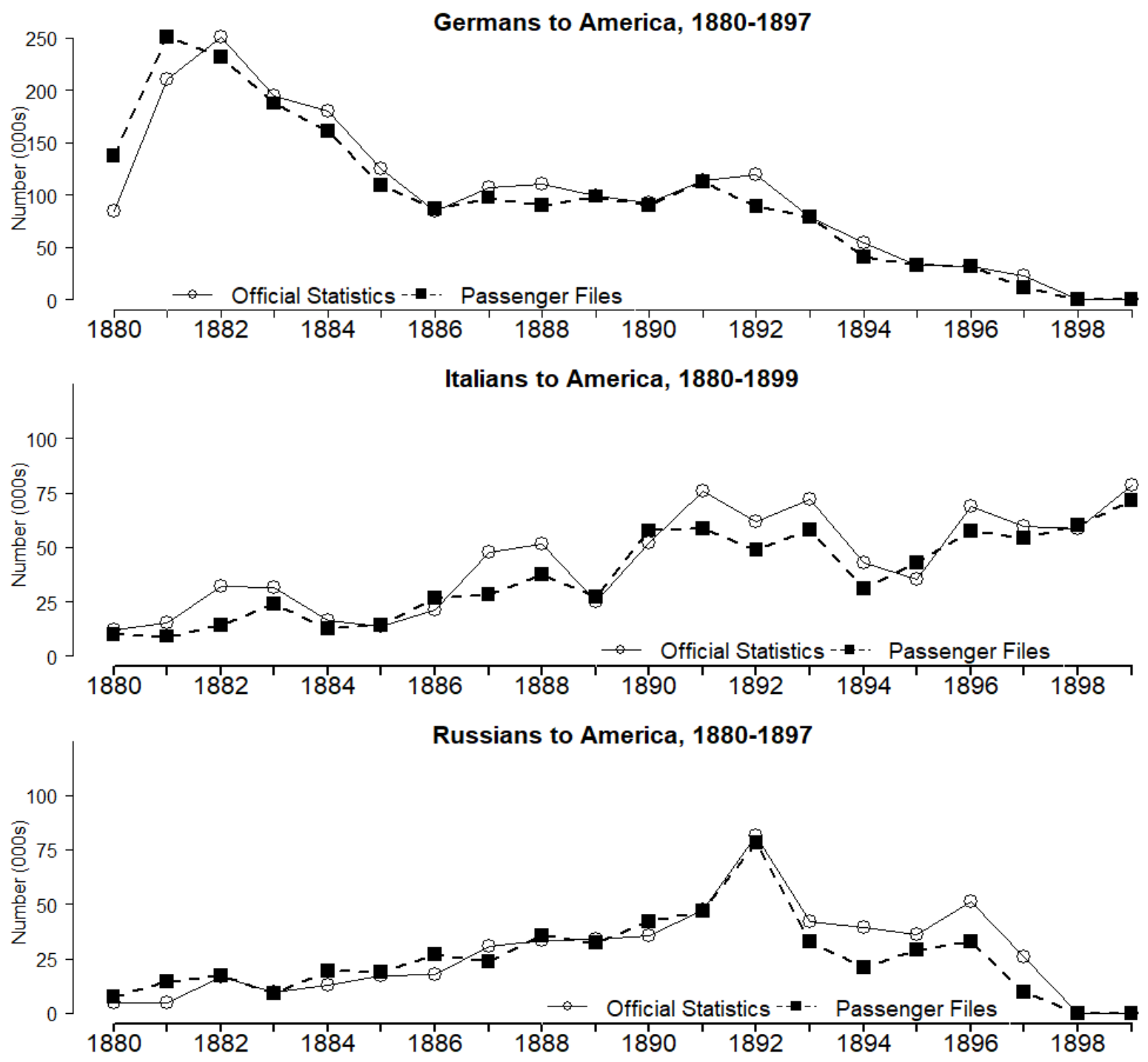

Figure A.1 Comparisons of passenger record data with US official statistics.

Sources: Author's calculations of the NARA data; Ferenczi and Wilcox (1929). 
Table 1: Descriptive statistics of passenger lists

\begin{tabular}{|c|c|c|c|c|c|}
\hline \multirow[b]{3}{*}{ Observations } & \multirow[t]{2}{*}{$\begin{array}{c}\text { Italians } \\
(1880-1899)\end{array}$} & \multicolumn{2}{|c|}{$\begin{array}{c}\text { Russians } \\
(1880-1897)\end{array}$} & \multicolumn{2}{|c|}{$\begin{array}{l}\text { Germans } \\
(1880-1897)\end{array}$} \\
\hline & & Jewish & Non-Jewish & Jewish & Non-Jewish \\
\hline & 416,896 & 131,196 & 78,930 & 298,814 & 367,906 \\
\hline Age at arrival (median) & 28 & 25 & 21 & 25 & 25 \\
\hline Age in 1900 (median) & 37 & 36 & 31 & 40 & 39 \\
\hline \multicolumn{6}{|l|}{ Occupation (percent) } \\
\hline White Collar & 2.89 & 9.21 & 5.87 & 13.66 & 13.01 \\
\hline Skilled & 9.77 & 14.55 & 10.35 & 16.96 & 18.53 \\
\hline Farmer & 13.79 & 5.80 & 11.04 & 24.42 & 25.50 \\
\hline Semi-skilled & 6.08 & 3.60 & 2.96 & 7.40 & 8.16 \\
\hline Unskilled & 67.46 & 66.84 & 69.78 & 37.57 & 34.79 \\
\hline \multicolumn{6}{|l|}{ Literate (percent) } \\
\hline Yes & 14.63 & 7.05 & 8.43 & 5.43 & 6.85 \\
\hline No & 17.11 & 5.28 & 5.91 & .78 & .80 \\
\hline Unknown & 68.26 & 87.67 & 85.65 & 93.78 & 92.35 \\
\hline \multicolumn{6}{|l|}{ Travel compartment (percent) } \\
\hline First/second class & 2.15 & 2.40 & 2.55 & 14.28 & 13.31 \\
\hline Steerage & 97.53 & 97.58 & 97.44 & 85.69 & 86.66 \\
\hline Stowaway/other & .32 & .02 & .01 & .03 & .03 \\
\hline \multicolumn{6}{|l|}{ Year of entry (percent) } \\
\hline $1880-1889$ & 25.61 & 40.33 & 38.14 & 75.01 & 69.52 \\
\hline $1890-1899$ & 74.39 & 59.67 & 61.86 & 24.99 & 30.48 \\
\hline Most common port of embarkation & Naples, Italy & $\begin{array}{l}\text { Hamburg, } \\
\text { Germany }\end{array}$ & $\begin{array}{l}\text { Hamburg, } \\
\text { Germany }\end{array}$ & $\begin{array}{l}\text { Bremen, } \\
\text { Germany }\end{array}$ & $\begin{array}{l}\text { Bremen, } \\
\text { Germany }\end{array}$ \\
\hline $\begin{array}{l}\text { Second most common port of } \\
\text { embarkation }\end{array}$ & $\begin{array}{l}\text { Le Havre, } \\
\text { France }\end{array}$ & $\begin{array}{l}\text { Bremen, } \\
\text { Germany }\end{array}$ & $\begin{array}{l}\text { Bremen, } \\
\text { Germany }\end{array}$ & $\begin{array}{l}\text { Antwerp, } \\
\text { Belgium }\end{array}$ & $\begin{array}{l}\text { Hamburg, } \\
\text { Germany }\end{array}$ \\
\hline $\begin{array}{l}\text { Most common port of } \\
\text { disembarkation }\end{array}$ & $\begin{array}{l}\text { New York, } \\
\text { New York }\end{array}$ & $\begin{array}{l}\text { New York, } \\
\text { New York }\end{array}$ & $\begin{array}{l}\text { New York, } \\
\text { New York }\end{array}$ & $\begin{array}{l}\text { New York, } \\
\text { New York }\end{array}$ & $\begin{array}{l}\text { New York, } \\
\text { New York }\end{array}$ \\
\hline
\end{tabular}

Source: author's calculations of NARA data

Note: Data are limited to men who are 25 to 65 in 1910 and arrived after 1880. Premigration occupations are classified according to the HISCLASS rubric: HISCLASS 1-5 white collar; HISCLASS 6-7 skilled blue-collar; HISCLASS 8 farmers; HISCLASS 9 semiskilled; HISCLASS 10-12 unskilled. 
Table 2: Descriptive Statistics of Matched Datasets

\begin{tabular}{|c|c|c|}
\hline & $\begin{array}{l}\text { First Generation Sample (Passenger } \\
\text { to } 1910 \text { Link) }\end{array}$ & $\begin{array}{l}\text { Second Generation Sample (1910 to } \\
\text { 1940 Link) }\end{array}$ \\
\hline & Mean/Proportion & Mean/Proportion \\
\hline Occscore $(\$ 2010)$ & $\begin{array}{c}21176.26 \\
(8520.553)\end{array}$ & $\begin{array}{c}23531.60 \\
(9681.193)\end{array}$ \\
\hline \multicolumn{3}{|l|}{ Premigration Status } \\
\hline White Collar & $\begin{array}{l}.094 \\
(.292)\end{array}$ & $\begin{array}{l}.095 \\
(.293)\end{array}$ \\
\hline Skilled & $\begin{array}{c}.171 \\
(.376)\end{array}$ & $\begin{array}{c}.175 \\
(.380)\end{array}$ \\
\hline Farmer & $\begin{array}{l}.216 \\
(.411)\end{array}$ & $\begin{array}{l}.245 \\
(.430)\end{array}$ \\
\hline Semi-Skilled & $\begin{array}{c}.071 \\
(.258)\end{array}$ & $\begin{array}{c}.069 \\
(.255)\end{array}$ \\
\hline Unskilled & $\begin{array}{l}.447 \\
(.497)\end{array}$ & $\begin{array}{l}.415 \\
(.493)\end{array}$ \\
\hline \multicolumn{3}{|l|}{ Ethnicity } \\
\hline Italian & $\begin{array}{l}.228 \\
(.450)\end{array}$ & $\begin{array}{l}.137 \\
(.344)\end{array}$ \\
\hline Jewish & $\begin{array}{l}.269 \\
(.443)\end{array}$ & $\begin{array}{l}.279 \\
(.449)\end{array}$ \\
\hline German & $\begin{array}{l}.454 \\
(.498)\end{array}$ & $\begin{array}{l}.540 \\
(.498)\end{array}$ \\
\hline Russian & $\begin{array}{l}.050 \\
(.218)\end{array}$ & $\begin{array}{l}.043 \\
(.204)\end{array}$ \\
\hline \multicolumn{3}{|l|}{ First Generation Arrival Age } \\
\hline 15 to 20 & $\begin{array}{l}.282 \\
(.450)\end{array}$ & $\begin{array}{l}.337 \\
(.473)\end{array}$ \\
\hline $21-25$ & $\begin{array}{l}.298 \\
(.457)\end{array}$ & $\begin{array}{l}.336 \\
(.473)\end{array}$ \\
\hline $26-30$ & $\begin{array}{l}.215 \\
(.411)\end{array}$ & $\begin{array}{l}.209 \\
(.406)\end{array}$ \\
\hline Over 30 & $\begin{array}{l}.205 \\
(.403)\end{array}$ & $\begin{array}{l}.118 \\
(.322)\end{array}$ \\
\hline \multicolumn{3}{|l|}{ Class of Ship } \\
\hline First/Second Cabin & $\begin{array}{c}.085 \\
(.279)\end{array}$ & $\begin{array}{c}.093 \\
(.291)\end{array}$ \\
\hline Third Cabin (steerage) & $\begin{array}{c}.914 \\
(.280)\end{array}$ & $\begin{array}{c}.887 \\
(.316)\end{array}$ \\
\hline Missing/Stowaway & $\begin{array}{c}.001 \\
(.027)\end{array}$ & $\begin{array}{c}.019 \\
(.138)\end{array}$ \\
\hline Second Generation Age (1910) & & $\begin{array}{l}10.093 \\
(5.191)\end{array}$ \\
\hline Observations & 149,683 & 53,296 \\
\hline
\end{tabular}

Note: Standard deviation in parentheses. Data are limited to men who are 25 to 65 in 1910 and arrived after 1880. Premigration occupations are classified according to the HISCLASS rubric: HISCLASS 1-5 white collar; HISCLASS 6-7 skilled blue-collar; HISCLASS 8 farmers; HISCLASS 9 semiskilled; HISCLASS 10-12 unskilled. 
Table 3: OLS estimates predicting first generation 1910 occupational income (in \$2010)

\begin{tabular}{|c|c|c|c|c|c|}
\hline \multirow{2}{*}{$\begin{array}{l}\text { Passenger List } \\
\text { Variables }\end{array}$} & & \multicolumn{3}{|c|}{ OCCSCORE } & $\begin{array}{c}\text { LN(OCCSCORE) } \\
\text { Model (5) }\end{array}$ \\
\hline & & & & & \\
\hline Premigration & & & & & \\
\hline $\begin{array}{l}\text { Occupation (white } \\
\text { collar ref.) }\end{array}$ & & & & & \\
\hline Skilled & $\begin{array}{r}-1091.990 * * * \\
(89.132)\end{array}$ & $\begin{array}{r}-1052.648 * * * \\
(89.258)\end{array}$ & $\begin{array}{r}-909.770 * * * \\
(90.711)\end{array}$ & $\begin{array}{r}-816.536 * * * \\
(95.257)\end{array}$ & $\begin{array}{r}-.029 * * * \\
(.004)\end{array}$ \\
\hline Farmer & $\begin{array}{r}-2450.100 * * * \\
(85.739)\end{array}$ & $\begin{array}{r}-2401.396 * * * \\
(85.836)\end{array}$ & $\begin{array}{r}-2217.138 * * * \\
(87.950)\end{array}$ & $\begin{array}{r}-1625.266 * * * \\
(92.801)\end{array}$ & $\begin{array}{r}-.069 * * * \\
(.004)\end{array}$ \\
\hline Semi-skilled & $\begin{array}{r}-1559.365 * * * \\
(108.557)\end{array}$ & $\begin{array}{r}-1495.371 * * * \\
(109.234)\end{array}$ & $\begin{array}{r}-1284.565^{* * *} * \\
(110.029)\end{array}$ & $\begin{array}{r}-1149.299 * * * \\
(112.625)\end{array}$ & $\begin{array}{r}-.045^{* * * *} \\
(.005)\end{array}$ \\
\hline Unskilled & $\begin{array}{r}-1956.909 * * * \\
(71.592)\end{array}$ & $\begin{array}{r}-1819.754 * * * \\
(80.577)\end{array}$ & $\begin{array}{r}-1693.253 * * * \\
(82.742)\end{array}$ & $\begin{array}{r}-1360.184 * * * \\
(87.919)\end{array}$ & $\begin{array}{r}-.056 * * * \\
(.004)\end{array}$ \\
\hline Ethnicity (Italian ref.) & & & & & \\
\hline Jewish & & $\begin{array}{r}622.464 * * * \\
(63.838)\end{array}$ & $\begin{array}{r}753.108 * * * \\
(75.617)\end{array}$ & $\begin{array}{r}1233.890 * * * \\
(77.839)\end{array}$ & $\begin{array}{r}.046 * * * \\
(.004)\end{array}$ \\
\hline German (non-Jewish) & & $\begin{array}{r}200.888 * * * \\
(58.393)\end{array}$ & $\begin{array}{r}334.334 * * * \\
(71.535)\end{array}$ & $\begin{array}{r}919.919 * * * \\
(74.245)\end{array}$ & $\begin{array}{r}.035 * * * \\
(.003)\end{array}$ \\
\hline Russian (non-Jewish) & & $\begin{array}{r}-576.138 * * * \\
(108.370)\end{array}$ & $\begin{array}{r}-816.348 * * * \\
(112.424)\end{array}$ & $\begin{array}{r}548.878 * * * \\
(104.106)\end{array}$ & $\begin{array}{r}.022 * * * \\
(.005)\end{array}$ \\
\hline $\begin{array}{l}\text { Arrival age ( } 15 \text { to } 20 \\
\text { ref.) }\end{array}$ & & & & & \\
\hline 21 to 25 & & & $\begin{array}{r}-644.866 * * * \\
(57.513)\end{array}$ & $\begin{array}{r}-551.934 * * * \\
(55.418)\end{array}$ & $\begin{array}{r}-.025 * * * \\
(.003)\end{array}$ \\
\hline 26 to 30 & & & $\begin{array}{r}-1264.690 * * * \\
(62.629)\end{array}$ & $\begin{array}{r}-1058.776 * * * \\
(60.426)\end{array}$ & $\begin{array}{r}-.048 * * * \\
(.003)\end{array}$ \\
\hline Over 30 & & & $\begin{array}{r}-2239.112 * * * \\
(63.564)\end{array}$ & $\begin{array}{r}-1925.119 * * * \\
(62.292)\end{array}$ & $\begin{array}{r}-.094 * * * \\
(.003)\end{array}$ \\
\hline $\begin{array}{l}\text { Class traveled on } \\
\text { (first/second cabin ref.) }\end{array}$ & & & & & \\
\hline Steerage & & & $\begin{array}{r}-240.204 * * \\
(83.579)\end{array}$ & $\begin{array}{r}-257.813 * * \\
(86.496)\end{array}$ & $\begin{aligned}-.009 * \\
(.004)\end{aligned}$ \\
\hline Stowaway/missing & & & $\begin{array}{r}-447.428 \\
(811.095)\end{array}$ & $\begin{array}{r}-95.611 \\
(787.964)\end{array}$ & $\begin{array}{r}-.004 \\
(.009)\end{array}$ \\
\hline 1910 Census Variables & & & & & \\
\hline Married & & & & $\begin{array}{r}1711.625 * * * \\
(58.553)\end{array}$ & $\begin{array}{r}.086 * * * \\
(.003)\end{array}$ \\
\hline Literate & & & & $\begin{array}{r}2590.841 * * * \\
(57.037)\end{array}$ & $\begin{array}{r}.107 * * * \\
(.003)\end{array}$ \\
\hline Fixed Effects & & & & & \\
\hline $\begin{array}{l}\text { Year of arrival fixed } \\
\text { effect (passenger) }\end{array}$ & No & No & Yes & Yes & Yes \\
\hline $\begin{array}{l}\text { State fixed effect } \\
(1910)\end{array}$ & No & No & No & Yes & Yes \\
\hline Constant & $\begin{array}{l}22879.780 * * * \\
(71.592)\end{array}$ & $\begin{array}{l}22567.160 * * * \\
(88.071)\end{array}$ & $\begin{array}{c}22877.71 * * * \\
(167.302)\end{array}$ & $\begin{array}{c}19619.410 * * * \\
(667.480)\end{array}$ & $\begin{array}{c}9.827 * * * \\
(.032)\end{array}$ \\
\hline Observations & 149,683 & 149,683 & 149,683 & 149,683 & 149,237 \\
\hline R-squared & .007 & .008 & .019 & .089 & .100 \\
\hline
\end{tabular}

$+.05<\mathrm{p}<.1, * \mathrm{p}<.05, * * \mathrm{p}<.01, * * * \mathrm{p}<.001$ (two-tailed)

Note: Standard errors in parentheses. Data come from the matched passenger record to 1910 census record. Data are limited to men who are 25 to 65 in 1910 and arrived after 1880. Premigration occupations are classified according to the HISCLASS rubric: HISCLASS 1-5 white collar; HISCLASS 6-7 skilled blue-collar; HISCLASS 8 farmers; HISCLASS 9 semiskilled; HISCLASS 10-12 unskilled. 
Table 4: OLS estimates predicting second generation 1940 occupational income (in \$2010)

\begin{tabular}{|c|c|c|c|c|c|}
\hline & \multicolumn{4}{|c|}{ OCCSCORE } & \multirow{2}{*}{$\frac{\text { LN(OCCSCORE) }}{\text { Model (5) }}$} \\
\hline & Model (1) & Model (2) & Model (3) & Model (4) & \\
\hline \multicolumn{6}{|l|}{ Passenger List Variables } \\
\hline \multicolumn{6}{|l|}{ Parental Premigration } \\
\hline \multicolumn{6}{|l|}{ Occupation (white } \\
\hline \multirow[t]{2}{*}{ Skilled } & $-580.336 * *$ & $-618.164 * * *$ & $-594.948 * * *$ & $-601.638 * * *$ & $-.023 * *$ \\
\hline & (168.880) & $(165.080)$ & $(167.907)$ & $(167.828)$ & $(.007)$ \\
\hline \multirow[t]{2}{*}{ Farmer } & $-1794.845 * * *$ & $-1218.640 * * *$ & $-1185.827 * * *$ & $-1180.185^{* * *}$ & $-.048 * * *$ \\
\hline & $(160.188)$ & $(157.162)$ & $(161.068)$ & $(161.003)$ & $(.007)$ \\
\hline \multirow[t]{2}{*}{ Semi-skilled } & $-598.393 * *$ & $-609.716^{* *}$ & $-567.889 * *$ & $-577.845^{* *}$ & $-.021 *$ \\
\hline & (208.914) & $(204.23)$ & $(206.489)$ & $(206.394)$ & $(.009)$ \\
\hline \multirow[t]{2}{*}{ Unskilled } & $-928.357 * * *$ & $-923.741 * * *$ & $-906.326 * * *$ & $-881.077 * * *$ & $-.035 * * *$ \\
\hline & $(150.757)$ & $(149.391)$ & $(153.435)$ & $(153.402)$ & $(.007)$ \\
\hline \multicolumn{6}{|l|}{ Ethnicity (Italian ref.) } \\
\hline \multirow[t]{2}{*}{ Jewish } & & $1059.027 * * *$ & $993.295 * * *$ & $683.272 * * *$ & $.024 * *$ \\
\hline & & $(146.356)$ & $(167.529)$ & (172.853) & $(.007)$ \\
\hline \multirow[t]{2}{*}{ German (non-Jewish) } & & $521.307 * * *$ & $445.284 * *$ & 117.243 & .006 \\
\hline & & $(137.540)$ & $(159.446)$ & $(165.707)$ & $(.007)$ \\
\hline \multirow[t]{2}{*}{ Russian (non-Jewish) } & & $722.134 * *$ & $602.241 *$ & $444.791+$ & .015 \\
\hline & & $(241.833)$ & $(251.106)$ & $(251.907)$ & $(.011)$ \\
\hline \multirow{2}{*}{\multicolumn{6}{|c|}{$\begin{array}{l}\text { Parental arrival age ( } 15 \\
\text { to } 20 \text { ref.) }\end{array}$}} \\
\hline & & & & & \\
\hline \multirow[t]{2}{*}{21 to 25} & & & $-365.912 * * *$ & $-349.880 * *$ & $-.015 * *$ \\
\hline & & & $(101.725)$ & (101.699) & $(.004)$ \\
\hline \multirow[t]{2}{*}{26 to 30} & & & $-520.066 * * *$ & $-481.424 * * *$ & $-.018 * * *$ \\
\hline & & & (117.766) & (117.828) & $(.005)$ \\
\hline \multirow[t]{2}{*}{ Over 30} & & & $-737.364 * * *$ & $-663.307 * * *$ & $-.028 * * *$ \\
\hline & & & (146.369) & (146.734) & $(.006)$ \\
\hline \multirow{2}{*}{\multicolumn{6}{|c|}{$\begin{array}{l}\text { Parental class traveled } \\
\text { on (first/second cabin } \\
\text { ref.) }\end{array}$}} \\
\hline & & & & & \\
\hline \multirow[t]{2}{*}{ Steerage } & & & 28.977 & 36.245 & -.002 \\
\hline & & & (148.909) & $(148.840)$ & $(.006)$ \\
\hline \multirow[t]{2}{*}{ Stowaway/missing } & & & -211.169 & -192.512 & -.008 \\
\hline & & & $(324.777)$ & $(324.630)$ & $(.014)$ \\
\hline 1910 Census Variables & & & & & \\
\hline Child's Age & & & $203.313^{* * *}$ & $199.304 * * *$ & $.009 * * *$ \\
\hline & & & $(31.714)$ & $(31.704)$ & $(.001)$ \\
\hline Child's Age Squared & & & $-8.165 * * *$ & $-8.052 * * *$ & $-.000 * * *$ \\
\hline & & & $(1.607)$ & $(1.606)$ & $(.000)$ \\
\hline Parental Marital Status & & & & 299.978 & .011 \\
\hline & & & & $(223.210)$ & $(.009)$ \\
\hline Parental Literacy Status & & & & $1211.329 * * *$ & $.046 * * *$ \\
\hline & & & & $(167.900)$ & $(.007)$ \\
\hline Fixed Effects & & & & & \\
\hline $\begin{array}{l}\text { Parental Year of arrival } \\
\text { fixed effect (passenger) }\end{array}$ & No & No & Yes & Yes & Yes \\
\hline $\begin{array}{l}\text { Parental State fixed } \\
\text { effect (1910) }\end{array}$ & No & Yes & Yes & Yes & Yes \\
\hline Constant & $24500.420 * * *$ & $21582.810 * * *$ & $21094.300 * * *$ & $20003.810 * * *$ & $9.800 * * *$ \\
\hline & $(136.039)$ & $(2294.068)$ & $(2310.317)$ & $(2322.546)$ & $(.099)$ \\
\hline Observations & 53,296 & 53,296 & 53,296 & 53,296 & 53,251 \\
\hline R-squared & .003 & .051 & .053 & .054 & .070 \\
\hline
\end{tabular}

$+.05<\mathrm{p}<.1, * \mathrm{p}<.05, * * \mathrm{p}<.01, * * * \mathrm{p}<.001$ (two-tailed)

Note: Standard errors in parentheses. Data come from the matched 1910 to 1940 census record. 
Table A.1: Match rates of first generation immigrants

\begin{tabular}{|c|c|c|c|c|c|}
\hline & $\begin{array}{c}\text { Passenger } \\
\text { Record Universe }\end{array}$ & $\begin{array}{l}1910 \text { Census } \\
\text { Universe }\end{array}$ & $\begin{array}{l}\text { Matched } \\
\text { Sample }\end{array}$ & $\begin{array}{c}\text { Forward } \\
\text { Match Rate }\end{array}$ & $\begin{array}{l}\text { Backward } \\
\text { Match Rate }\end{array}$ \\
\hline & $\mathrm{A}$ & $\mathrm{B}$ & $\mathrm{C}$ & (C/A) & $(\mathrm{C} / \mathrm{B})$ \\
\hline Observations & $1,293,742$ & 707,898 & 149,683 & .116 & .211 \\
\hline \multicolumn{6}{|c|}{ Premigration Occupation } \\
\hline White Collar & 117,466 & & 14070 & .119 & \\
\hline Skilled & 186,854 & & 25580 & .137 & \\
\hline Farmer & 240,619 & & 32400 & .135 & \\
\hline Semi-skilled & 84,554 & & 10690 & .126 & \\
\hline Unskilled & 664,249 & & 66943 & .101 & \\
\hline \multicolumn{6}{|l|}{ Ethnicity } \\
\hline Italian & 416,896 & 142,119 & 34078 & .082 & .239 \\
\hline Jewish & 430,010 & 170,186 & 40190 & .093 & .236 \\
\hline German & 367,906 & 325,379 & 67921 & .185 & .209 \\
\hline Russian & 78,930 & 70,214 & 7494 & .095 & 107 \\
\hline \multicolumn{6}{|l|}{ Arrival Age } \\
\hline 15 to 20 & 267,803 & 245,966 & 42310 & .158 & .172 \\
\hline 21 to 25 & 363,753 & 199,826 & 44546 & .122 & .223 \\
\hline 26 to 30 & 299,320 & 109,366 & 32187 & .108 & .294 \\
\hline Over 30 & 362,866 & 152,740 & 30640 & .084 & 201 \\
\hline \multicolumn{6}{|l|}{ Travel compartment } \\
\hline First/second class & 105,765 & & 12,754 & .121 & \\
\hline Steerage & $1,186,443$ & & 136819 & .115 & \\
\hline Stowaway/other & 1,534 & & 110 & .072 & \\
\hline \multicolumn{6}{|c|}{ Year of entry (percent) } \\
\hline $1880-1889$ & 669,673 & 370,999 & 81710 & .122 & .220 \\
\hline 1890-1899 & 624,069 & 336,899 & 67973 & .109 & .202 \\
\hline \multicolumn{6}{|l|}{ Literacy (1910) } \\
\hline Not Literate & & 86,443 & 18227 & & .211 \\
\hline Literate & & 621,455 & 131456 & & .222 \\
\hline \multicolumn{6}{|l|}{ Marital Status (1910) } \\
\hline Not Married & & 101,291 & 23006 & & .227 \\
\hline Married & & 606,607 & 126677 & & 209 \\
\hline
\end{tabular}

Note: The data universe for the passenger records includes all male immigrants who arrived from Germany, Italy, and Russia. These immigrants were over the age of 15 at arrival and would be 25 to 65 in 1910 . Those who arrived as US citizens are dropped from this universe. The 1910 census universe includes all immigrants born in Germany, Italy, and Russia and report arriving between 1880 and 1899 with the same age exclusions as the passenger record universe. 
Table A.2: Match rates of second generation children

\begin{tabular}{|c|c|c|c|}
\hline & $\begin{array}{l}\text { Universe of Children of } \\
\text { Matched First Generation } \\
\text { Immigrants }\end{array}$ & Matched Sample & Match Rate \\
\hline & 115,410 & 53,296 & .46 \\
\hline \multicolumn{4}{|c|}{$\begin{array}{l}\text { Observations } \\
\text { Father's Premigration Occupation }\end{array}$} \\
\hline White Collar & 10,115 & 5,049 & .50 \\
\hline Skilled & 19,557 & 9,331 & .48 \\
\hline Farmer & 25,271 & 13,062 & .52 \\
\hline Semi-skilled & 7,715 & 3,717 & .48 \\
\hline Unskilled & 52,752 & 22,137 & .42 \\
\hline \multicolumn{4}{|l|}{ Father's Ethnicity } \\
\hline Italian & 26,842 & 7,284 & .27 \\
\hline Jewish & 30,832 & 14,911 & .48 \\
\hline German & 51,302 & 28,783 & .56 \\
\hline Russian & 6,434 & 2,318 & .36 \\
\hline \multicolumn{4}{|l|}{ Father's Arrival Age } \\
\hline 15 to 20 & 36,804 & 17,952 & .49 \\
\hline 21 to 25 & 38,934 & 17,946 & .46 \\
\hline 26 to 30 & 24,506 & 11,118 & .45 \\
\hline Over 30 & 15,166 & 6,280 & .41 \\
\hline \multicolumn{4}{|c|}{ Father's Travel compartment } \\
\hline First/second class & 9,719 & 4,981 & .51 \\
\hline Steerage & 103,252 & 47,287 & .46 \\
\hline Stowaway/other & 2,439 & 1,028 & .42 \\
\hline \multicolumn{4}{|c|}{ Father's Year of entry (percent) } \\
\hline $1880-1889$ & 60,224 & 31,511 & .52 \\
\hline $1890-1899$ & 55,186 & 21,785 & .39 \\
\hline \multicolumn{4}{|l|}{ Son's Age in 1910} \\
\hline 0 to 5 & 27,900 & 12,196 & .44 \\
\hline 6 to 10 & 37,208 & 14,317 & .38 \\
\hline 11 to 15 & 29,668 & 16,716 & .56 \\
\hline 15 to 18 & 20,634 & 10,067 & .49 \\
\hline
\end{tabular}

Note: Data Universe for the second generation includes all children in the 1910 census with a father who is linked to his passenger record. 
Table A.3: Means of the matched samples and data universe

\begin{tabular}{lccc}
\hline & Matched Sample & Data Universe & $\begin{array}{c}\text { Difference (matched - } \\
\text { population) }\end{array}$ \\
\cline { 2 - 4 } First Generation & $21176.260(8520.553)$ & $20801.77(8334.85)$ & 374.49 \\
Occscore & $47.304(8.812)$ & $51.598(6.895)$ & -4.294 \\
Age & $87.823(32.702)$ & $82.6(37.9)$ & 5.223 \\
Literate & $84.630(36.066)$ & $85.4(.35 .3)$ & -.770 \\
Married & & & .122 \\
Second Generation & & & .082 \\
Son's Age, 1910 & $10.093(5.191)$ & $9.971(5.227)$ & -308.06 \\
Father's Marital Status & $96.510(18.353)$ & $96.428(.186)$ & .018 \\
Father's Occscore, 1910 & $20683.72(8496.934)$ & $20991.780(8358.062)$ & \\
Father's Age, 1910 & $45.665(7.053)$ & $45.647(7.238)$ & \\
\hline
\end{tabular}

Note: Data universe comes from Table A.1 for the first generation and Table A.2 for the second generation.

Table B.1: Intergenerational elasticities of father-son pairs, 1910-1940

\begin{tabular}{|c|c|c|c|c|}
\hline Sample & IGE & $\begin{array}{l}\text { IGE (with state } \\
\text { fixed effect) }\end{array}$ & Observations & Clusters \\
\hline Pooled & $\begin{array}{r}.239 * * * \\
(.012)\end{array}$ & $\begin{array}{r}.174 * * * \\
(.011)\end{array}$ & 52467 & 34665 \\
\hline Italians Only & $\begin{array}{r}.069 * * \\
(.026)\end{array}$ & $\begin{array}{r}.071 * * \\
(.026)\end{array}$ & 7218 & 5366 \\
\hline Jewish Only & $\begin{array}{r}.294 * * * \\
(.022)\end{array}$ & $\begin{array}{r}.215^{* * * *} \\
(.021)\end{array}$ & 14651 & 9673 \\
\hline Germans Only & $\begin{array}{r}.277 * * * \\
(.016)\end{array}$ & $\begin{array}{r}.205 * * * \\
(.016)\end{array}$ & 28310 & 18103 \\
\hline Russians Only & $\begin{array}{r}.286 * * * \\
(.055)\end{array}$ & $\begin{array}{l}.143 * \\
(.056)\end{array}$ & 2288 & 1539 \\
\hline
\end{tabular}

$+.05<\mathrm{p}<.1, * \mathrm{p}<.05, * * \mathrm{p}<.01, * * * \mathrm{p}<.001$ (two-tailed)

Note: intergenerational elasticities are calculated from the second-generation sample described in the text.

Standard errors are clustered at the family-level. 